\title{
Jasenovačke žrtve i uspostava nacionalnog programa u Srbiji (1986. - 1995.)
}

\begin{abstract}
Žrtve Drugoga svjetskog rata, a napose jasenovačke zauzimaju istaknuto mjesto u hrvatskoj i srpskoj nacionalnoj memoriji te su još i danas nadasve osjetljiva viktimološka tema. Vrlo rano tema je zbog potreba jugoslavenske ideologije izrasla u prvorazredno političko pitanje podložno manipulaciji i zlouporabi. U članku se nastoji rekonstruirati stvaranje propagandnog okvira u kojemu su se ratne i jasenovačke žrtve zloupotrebljavale neodgovornim i neumjesnim spekulacijama. Uoči ratnog raspada SFRJ one su postale sredstvom ratne propagande, a u procesu osamostaljivanja Hrvatske i nakon njega zbog velikog se broja jasenovačkih žrtava žigosao cijeli narod. Razlog za dugotrajnu diskusiju, tijekom koje su u prvi plan izbili sučeljeni pogledi na zajedničko povijesno iskustvo hrvatskog i srpskog naroda, ne pridonoseći rješavanju međusobnih odnosa, zasigurno je sama složena priroda problema. Uzroci se možda mogu tražiti i u tome što je publicistika preuzimala posao povjesničara, a profesionalni povjesničari postajali su sredstvom propagande.
\end{abstract}

\section{Uvod}

Nestabilne jugoslavenske prilike koje je opterećivala dugogodišnja ekonomska kriza radikaliziralo je političko usredotočenje Srbije na preinaku Ustava iz 1974. i očigledna suprotstavljenost gledišta oko temeljnih društveno-političkih pitanja. ${ }^{1}$ Događaji iz 1986. godine poslužili su kao osnova na kojoj se pojačavao sukob oko godinama potiskivanih tema, od formiranja zajedničke južnoslavenske države, preko 1941. - 1945., do raspada federacije 1990./1991. Sa sve prisutnijim srpskim nacionalizmom aktualizirale su se teme iz Drugog svjetskog rata i uloga pojedinih nacija u njemu: dovode se u pitanje unutarnje granice, tvrdi se kako je od 1945. do 1951. industrija iz Srbije premještena u Sloveniju i Hrvatsku kako

\footnotetext{
Godine 1987. stopa inflacije bila je $167 \%$, a 1988. 250\%, dok je ukupni vanjski dug SFRJ, prema izvještaju HNB-a, na dan 30. rujna 1991. bio 16,5 milijardi američkih dolara. Vidi KAČAN 2000: 1. Prema podacima Narodne banke Jugoslavije, ,,srednjoročni i dugoročni spoljni dug SFRJ je na dan 31. XII. 1991. iznosio 15,6 milijardi dolara, a ukupni dug 16,1 milijardu dolara." Narodna banka Jugoslavije. Godišnji izveštaj 1991: 45.
} 
bi se oslabila Srbija te da je Ustav iz 1974. nametnut Srbiji, a da su autonomne pokrajine tvorevine smišljene antisrpske koalicije. ${ }^{2}$

Angažirani su i autoriteti od nacionalnog ugleda: Srpska pravoslavna crkva, Udruženje književnika Srbije, Srpska akademija nauka i umetnosti te nekolicina pojedinaca od kojih najmarkantnije uloge imaju Dobrica Ćosić i Slobodan Milošević. U svibnju 1986. na scenu dolazi Slobodan Milošević kao predsjednik srbijanskih komunista koji je iskoristio uvjete za politički zaokret u SFRJ. U profiliranju srpske opozicije, a i u vezi s djelovanjem SANU, veliku je ulogu imao Dobrica Ćosić. U svojim je govorima često ponavljao tezu srpskog književnika, autora Triptihona, Tanasija Mladenovića, kako su „Srbi gubitnici u miru a pobjednici u ratu“.”.

Razumijevanje vlastitog identiteta u srpskom je nacionalnom diskursu stvaralo dojam Jugoslavije „koja je postala ravnodušna prema srpskim mukama i stradanjima“" te je Srbi više nisu mogli smatrati svojom državom. Ona je, prema Dobrici Ćosiću, postala ,neodrživa, nepodnošljiva, puki srpski mazohizam“. Napisi u tisku sugerirali su kako je „dugo vođena štetna politika po interese Jugoslavije i Srbije“ i vodila je jednom određenom cilju - „destabilizaciji socijalističke Jugoslavije.“4 Naglašavalo se: „hoćemo da ispravimo nepravdu nanijetu srpskom narodu Ustavom iz 1974. koji je Srbiju razdrobio na tri dijela i učinio je nemoćnom da brani svoj interes i teritorij. “5

\section{Tumačenje identiteta Srbije i postavljanje smjernica za provedbu srpskog nacionalnog programa}

Sredinom osamdesetih u tisku u Srbiji otvaraju se historiografske teme koje su do tada bile zabranjene. Uoči raspada SFRJ ustaški logor Jasenovac došao je u središte srpskog narativa, a potom je redefiniran kao sinonim za sva srpska stradanja. Rasprava o njemu sasvim sigurno ima političko-publicističku i povijesnu dimenziju, a u Srbiji kao modus operandi srpske velikodržavne koncepcije dnevne novine postaju sredstvom manipulacije u oblikovanju javnog mišljenja i tumačenja novije prošlosti.

Godine 1986. SANU je osnovao Odbor za izučavanje Srba u Hrvatskoj na čelu s akademikom Vasilijem Krestićem, jednim od autora Memoranduma SANU. ${ }^{6}$

2 Zdravko Tomac: „Imao sam sreću da sam aktivno sudjelovao u svim fazama stvaranja Ustava iz 1974. Mogu reći da je autoritet Tita i Kardelja bio presudan prilikom opredjeljenja da neka od ovih rješenja uđu u Ustav“. Vidi u VUČELIĆ 1986: 3, 4.

3 JOVANOVIĆ 1989: 14, 15.

4 POPOVIĆ 1989: 9.

5 TANJUG 1990: 7.

6 Odbor za izučavanje Srba u Hrvatskoj, s akademikom Dušanom Čalićem na čelu, osnovan je 1984., a aktivno je djelovao od 1986. godine. Jednako kao i Odbor za izučavanje genocida nad 
Odbor je prvenstveno bio usmjeren na hrvatske Srbe koji su bili afirmirani kao nositelji buduće provedbe srpskog nacionalnog programa formiranjem autonomija. Odbor je prestao s radom 1994. godine.

Drugi Odbor koji je također aktiviran 1986., a kojim je SANU ostvarivao izravan utjecaj na poziciju Srba u SFRJ, bio je Odbor za izučavanje genocida nad srpskim narodom kojemu je na čelu bio Vladimir Dedijer. ${ }^{7}$ Dedijer je od Russellova suda u kojemu je djelovao preuzeo termin „genocid“8 te ga 1972. prvi put upotrijebio pišući poglavlja u knjizi Istorija Jugoslavije, vezujući ga za ustašku politiku prema Srbima, ali i za odnos četničkog pokreta Draže Mihailovića i Milana Nedića prema Muslimanima i Hrvatima. Termin genocid primijenio je u širokom spektru: na austrougarsku politiku prema Srbiji, na Albance na Kosovu u vezi s njihovim odnosom prema tamošnjim Srbima i Crnogorcima te za osporavanje velikonacionalnog srpskog programa kojemu daje defenzivnu crtu, obilježavajući ga kao „obrambeni“. Od 1986. SANU je kroz Odbor za genocid posredno promicao sjećanja na srpsko stradanje u NDH na znanstvenim okupljanjima kojima je tema bila logor u Jasenovcu. Na tim je skupovima i raspravama pod prividom znanosti procjena 700 tisuća mrtvih u Jasenovcu postala formulom koja nije trpjela osporavanja. ${ }^{9}$

Uključivanjem akademika Vasilija Krestića u raspravu o problemu srpsko-hrvatskog odnosa Jasenovac se pojavio kao ključni argument u dokazivanju teze o genocidnosti Hrvata. Krestićev tekst $O$ genezi genocida nad srpskim narodom u $N D H$, koji je objavljen 15. rujna 1986. godine, desetak dana prije Memoranduma, najavljen je kao djelo koje ,ukazuje na duboke korene genocida nad Srbima u

srpskim narodom, ugašen je 1994. godine. Prvospomenuti Odbor imao je zadatak signalizirati sve probleme koji su na bilo koji način vezani s „bićem Srba u Hrvatskoj“. U tom je kontekstu najprije trebalo detektirati stanje Srba u Hrvatskoj i „obrazovanje u krajevima u kojima najveći dio stanovništva čini srpski narod, kako se koriste ćirilica i latinica, to smatramo gorućim pitanjem." U tijesnoj interakciji s političkim previranjima 1989. godine SANU je posredno kroz Odbor za istoriju Srba u Hrvatskoj priredio izlazak prvog sveska edicije Zbornika o Srbima u Hrvatskoj s 406 stranica kojemu je urednik Vasilije Krestić. Cilj je Zbornika bio istaknuti „markantna mjesta srpske povijesti“ i ulogu „hrvatskih Srba“ koja je, prema Krestiću, bila oskudna i „malo proučena“. Knjiga je bila namijenjena i inozemnom auditoriju s ciljem da se „,iz prve ruke obavijeste o osnovnoj činjenici da je srpski elemenat u povijesti Hrvatske mnogo veći i značajniji nego što se misli.“”

7 Godine je 1984. SANU osnovao Odbor za prikupljanje građe o genocidu na inicijativu Vladimira Dedijera, a aktivira ga 1986. godine.

8 Pojam genocid rabio je i Albert Vajs referirajući se na Jasenovac i Staru Gradišku i ne primjenjujući ga isključivo na židovsku populaciju. Vidi VAJS 1957: 8, 12, 32. Vajs je ,posle Oslobođenja radio u Državnoj komisiji za utvrđivanje zločina okupatora i njihovih pomagača; kao delegat Vlade FNRJ sudjelovao u Međusavezničkom vojnom tužilaštvu pri Međunarodnom vojnom sudu u Nürnbergu." Enciklopedija Jugoslavije 8: 449. Sudjelovao je u izradi elaborata za izručenje Artukovića. Vidi KANDIĆ 1964: 158.

9 RAPAIĆ 1991: 21; ŠARAC 1995: 5; ŠEATOVIĆ 1994: 1, 2; TANJUG 1994: 3. 
Hrvatskoj“.${ }^{10} \mathrm{U}$ tom tekstu dominira usmjerenost na dokazivanje „,netrpeljivosti prema Srbima u Hrvatskoj, koja se u Drugom svjetskom ratu pretvorila u jedan od najstrašnijih genocida u povijesti čovječanstva." Usto, iz pojedinačnih primjera koje navodi u tekstu Krestić uvjerava kako je moguće „dokazati postojanje, u poslednja tri veka, netrpeljivosti, potom i mržnje, kao i planova za uništavanje srpskog naroda. “11 „Bez dvoumljenja se može zaključiti“, ustvrđuje Krestić, kako se čekao pogodan trenutak da se „na najgrozniji način - pokoljima, vešanjima, streljanjima, izgladnjivanjem, prekrštavanjem, iseljavanjem itd. - za svagda mogu osloboditi Srba. Kako im to nije pošlo za rukom u prvom svetskom ratu, strpljivo su sačekali drugi. Priliku koja im se tada ukazala iskoristili su kolikogod su mogli (...) dugotrajno nastajanje genocidne ideje u određenim sredinama hrvatskoga društva (...) nije imalo tako usku nego prilično široku bazu, duboko se ukorenilo u svest mnogih generacija. "12

Potaknut nizom refleksija sličnih tema o NDH i društveno-političkih previranja u SFRJ te godine, Krestić je svojim tekstom nastojao uokviriti sva izdanja. Nakon ponovljenog izdanja Magnum crimena Viktora Novaka, pojava dvosveščane knjige Antuna Miletića Koncentracioni logor Jasenovac, knjige Alojzije Stepinac: zločinac ili svetac Branimira B. Stanojevića, a naročito sudski proces Andriji Artukoviću započet 1986. potaknuli su novi interes za pitanje genocida „koji je zadesio Srbe u NDH“".

Potkraj rujna 1986. godine Memorandum Srpske akademije nauka i umetnosti dospijeva u javnost i sve se intenzivnije koristi kao dokaz za promašen politički sustav Jugoslavije koji je postao poguban samo za srpski narod i Srbiju. Akademik Matija Bećković to je zorno sažeo: „Ni iz jednog rata nismo izašli toliko nagrđeni i osakaćeni kao iz 50-godišnjeg mira“" ${ }^{13}$ S obzirom na široke reakcije koje je izazvala pojava teksta, tadašnja je vlast vršila pritisak na akademike da se distanciraju od njega, ali su oni, uz ograde da je tekst ,radna verzija“, pojasnili kako je to ,interni dokument koji je na nemoralan način zloupotrebljen." Iako se Jasenovac izrijekom ne navodi u Memorandumu, u njegovu dijelu u kojemu se analizira stanje Srba u Hrvatskoj ustvrđuje se kako „izuzimajući period postojanja NDH, Srbi u Hrvatskoj nikada u prošlosti nisu bili toliko ugroženi koliko su danas. "'14 Tako se položaj Srba u Hrvatskoj u tom trenutku nameće kao najpreče političko pitanje. „Ukoliko se rešenja ne pronađu posledice mogu biti višestruko štetne ne samo po odnose u Hrvatskoj nego i po čitavu Jugoslaviju“. Rasprava o Memorandumu

\footnotetext{
10 LJUŠTIĆ 1989: 21.

11 KRESTIĆ 1986: 4.

12 Isto.

13 MILOSAVLJEVIĆ 1995: 49.

14 ĐUKANOVIĆ 1986a: 2; ĐUKANOVIĆ 1986b: 2 (skraćena verzija oba teksta: ĐUKANOVIĆ 1989: 48, 49).
} 
intenzivirala se do kraja 1986. i dijela 1987. godine, odnosno do Miloševićeva dolaska na vlast, kada je uspostavljen novi odnos prema Memorandumu. Tu je spregu ukratko pojasnio Dobrica Ćosić: „,mi smo podržali Miloševića u njegovim namerama da se Srbija ujedini, i sada moramo postaviti pitanje demokracije koja je od suštinskog značenja za srpski narod." ${ }^{15}$

Usponom Miloševića na vlast 1987. preuveličavanje broja jasenovačkih žrtava poprimilo je kampanju koja je ponajviše utjecala na instrumentalizaciju Srba u Hrvatskoj te se tvrdnjama o visokom broju žrtava opravdavao rat u koji su Srbi s Crnogorcima, JNA i dio Srba u Hvatskoj i BiH krenuli 1991. godine. U realizaciji Miloševićeve politike veliku su ulogu imali neki srpski dnevni i tjedni listovi koji su smišljeno isticali ustaške zločine iz Drugog svjetskog rata i povezivali ih s aktualnom situacijom te dodatno pojačavali napetost i neprijateljstvo. Režimski dnevni list Politika postao je nakon rujna 1987. najmoćnije Miloševićevo oružje za ostvarivanje ciljeva iz Memoranduma. ${ }^{16}$ Politikina rubrika Odjeci $i$ reagovanja, koja je uvedena u srpnju 1988. i trajala do ožujka 1991. kao ,glas naroda“ i „vreme kada je narod govorio“, donijela je 4.122 priloga. Za ovu je rubriku, koja je ocijenjena kao ,uređivački poduhvat i zapaženi doprinos razvoju novinarstva“, Živoradu Minoviću dodijeljena nagrada „Dimitrije Davidovićc"kao najviše novinarsko priznanje za uredničko-novinarski rad u 1988./1989. godini. Prema analizi Politikinih članaka tijekom 1991., autori se u 9.453 slučaja ne pozivaju ni na kakav izvor, na službene se izvore pozivaju u 1.080 članaka, a neposredan uvid autora ostvaren je u 472 slučaja. ${ }^{17}$ Prema nekim tvrdnjama, i sâm je Borisav Jović pisao za rubriku Odjeci i reagovanja pod pseudonimom. ${ }^{18}$

\section{BAČIĆ 1989: 3.}

16 Nekoliko je prijelomnih trenutaka iz 1987. promoviralo Miloševića kao ključnu figuru srbijanske politike. On je najprije odbacio „Stambolićevu taktiku pregovaranja s republikama radi promjene Ustava 1974.“, a napetu je situaciju ojačala i antialbanska histerija podjarivana novinskim člancima u Srbiji. Nakon događaja u paraćinskoj vojarni ,nastaje kvalitativna promjena u javnom mnjenju Srbije. Posle svega u sredstvima javnog informisanja“, naposljetku se iskonstruiralo kao uvod u konačan obračun za vlast u Srbiji koji je verificiran Osmom sjednicom CK SK Srbije održanom 23. i 24. rujna 1987. Nakon slabljenja pozicije predsjednika Predsjedništva SR Srbije Ivana Stambolića razrješenjem dužnosti i uklanjanjem iz Partije njegovih istomišljenika, kao i iz medija, on je sâm prikazan kao „,kompromiser koji nije dorastao dramatičnoj situaciji“. Na samoj je sjednici ,uspostavljena praksa, kasnije razrađena u Politici, u rubrici Odjeci i reagovanja“ da se telegramima ,građana“, odnosno „,naroda“ posvećuje velika pozornost, a osnažena je Miloševićevom maksimom kako je ,narod prevazišao partiju.“ Nakon Osme sjednice iz Miloševića je kabineta najavljena mjera tzv. diferencijacije (eufemizam za „,čistku“) koja je išla u pravcu smjene rukovodstava i pojedinaca uz Politiku kao glavnu polugu za obračun s „otuđenim birokratama“, a koja je „,obezglavila Srbiju u tom kadrovskom smislu za normalno rasuđivanje, za uključivanje u evropske integracije“. Detaljnije vidi LEKIĆ I PAVIĆ 2007; ĆURUVIJA I STAMBOLIĆ 2006: 89, 90; BILANDŽIĆ 1999: 732.

17 Beogradska agencija za primijenjena sociološka i politološka istraživanja „Argument“" analizirala je pisanje lista Politika tijekom 1991. Vidi VEKARIĆ 2011: 97.

18 VEKARIĆ 2011: 387. 
Ovom se rubrikom pripremalo za rat i neprijateljstvo prema ostatku Jugoslavije, iako se napisima i temama u njoj htio nametnuti dojam kako je narod taj koji je potaknuo političke poteze aktualne srbijanske vlasti i pozvao na obračun $\mathrm{s}$ vodstvima iz drugih republika. ${ }^{19}$

Ilustracije radi, samo je 1990. u Politici objavljeno oko 100 članaka u kojima se spominje Jasenovac (nisu ubrojeni napisi koji govore o novoj „ustaškoj“ hrvatskoj vlasti), a nerijetko se samo na jednoj stranici moglo naći po nekoliko članaka o Pavelićevoj „košari punoj srpskih očiju“, ,zaklanom narodu“ te opasnosti za srpski narod u Hrvatskoj. Neraščišćen broj žrtava u Drugom svjetskom ratu te manipuliranje i preuveličavanje jasenovačkih žrtava bili su propagandno sredstvo kojim su se Hrvati etiketirali kao „genocidna“ nacija te davao legitimitet „samoobrani“ Srba u Hrvatskoj i nasilju započetom 1990. godine. Iz bogatog vokabulara propagande protiv Hrvata koristili su se izrazi poput „,srbožderstvo“, „Zaklani narod“, „ostatak zaklanog naroda“, „najveći zaklani grad“. Isticalo se kako su Hrvati nakon pola stoljeća Srbima „,namenili nove Jasenovce, nove jame“, a Hrvatska se žigosala kao „koljačka ustaška država“ i izjednačavala s NDH, dok se hrvatstvo izjednačavalo s ustaštvom.

Impuls u oblikovanju javnog mišljenja dao je i srpski književnik i dopisni član SANU Petar Džadžić knjigom Nova ustaška država?. Objavljena je $1990 .{ }^{20}$ te, prema Džadžiću koji je aktualan politički trenutak u Hrvatskoj povezao s NDH, „upozorava što se može dogoditi u neposrednoj budućnosti“, ona je „knjiga protiv genocida“ “. ${ }^{21}$ U Politikinom svetu su tijekom travnja i svibnja 1990. u nastavcima objavljivani dijelovi Džadžićeve knjige u kojima on iznosi teze „o genocidnoj ostravljenosti na srpski narod“ koja se „oblikovala u drugoj polovini XIX veka“ te kako je „satanizacija Srba zasnovana na Starčevićevoj tezi o Srbima kao poluljudima koje treba potamaniti.“22

Informativan prostor u Srbiji bio je napose 1990. gusto nabijen ovakvim tezama te se Srbe u Hrvatskoj alarmantno upozoravalo na moguće ponavljanje ustaških zločina. Dobrica Ćosić je u svojim istupima tvrdio kako se Hrvatska „preko Srba u Hrvatskoj obračunava sa Srbijom“ te kako je „srpska sudbina u Hrvatskoj u ratu - genocid, a u socijalističkom miru - diskriminacija i asimilacija."U takvim je uvjetima Krestićevo aktualiziranje Jasenovca, uokvireno rečenicom akademika Matije Bećkovića „oni [Srbi u Hrvatskoj] su ostatak zaklanog naroda“, poput poziva na mobilizaciju.

Vidi analize u JOVANOVIĆ I TONČIĆ 2002. Također i KRIŽE 2015.

20

Nova ustaška država?, Politika 17. listopada 1990., 40.

21 DŽADŽIĆ 1990b: 6, 7; DŽADŽIĆ 1990a: 4-6.

22 DŽADŽIĆ 1990c: 1, 35-49; DŽADŽIĆ 1990b: 6,7. 


\section{Hrvatski narativ $i$ historiografija u desetljeću od 1986. do 1995. godine}

Uoči i nakon osamostaljenja Hrvatske bilo je sve više povijesnih tema, ali se njima nisu bavili etablirani povjesničari, nego političke poruke koje su utjecale na percepciju javnosti. Kao odgovor na ranija preuveličavanja žrtava jasenovačkog logora u srpskom propagandističkom diskursu, hrvatska je interpretacija Jasenovca, manje u Tuđmanovom, ali zato osobito u Omrčaninovu viđenju, također pokazala zastranjenja suprotnoga predznaka od srpske. Ona se tiču karaktera koncentracijskog logora Jasenovca koji se predstavljalo kao isključivo radni logor te umanjivanja broja jasenovačkih žrtava, a s druge strane favoriziranja onih blajburških.

Od 1989. hrvatska nacionalistička interpretacija povijesti pojavila se u napisima intoniranim u obranu Hrvatske s novim uvidom koji je težio umanjiti brojke kojima se dotad baratalo u vezi s jasenovačkim žrtavama. Taj je uvid usko povezan s interpretacijom povijesnih tema prvog hrvatskog predsjednika Franje Tuđmana koji je bio i predsjednik HDZ-a, a ujedno je nastupao s pozicije povjesničara. U pet izdanja svoje knjige Bespuća povijesne zbiljnosti (1989. dva izdanja, treće i četvrto 1990. te peto 1994.) i engleskog revidiranog izdanja Horrors of War: Historical Reality and Philosophy Tuđman apelira na ,potrebu objektivnog istraživanja svih 'sabirnih' i 'radnih' logora i Jasenovca prije svega. “23 U daljnjoj obradi ove teme autor ne osporava zločine i likvidacije u Jasenovcu, pri čemu kaže: ,,a istina je da je logor bio organiziran kao 'radni logor' s mnoštvom poljodjelskih i tvorničkoobrtničkih radnih jedinica“. U pokušaju izračuna jasenovačkih žrtava Tuđman navodi kako su ,u logor u manjim skupinama od po nekoliko desetaka ili stotina dopremane tisuće, pa i deseci tisuća nesretnih ljudi, ali i otpuštane, i otpremane u logore i na rad u Njemačku. Zatočenici su za sve vrijeme bili iscrpljivani i mrcvareni pod nevjerovatno teškim uvjetima a pri tom su i mučeni i ubijani za najmanji neposluh pojedinačno - osobito iznemogli i stari, a povremeno, obično pod izlikom odmazde za poginule ustaše ili za pokušaj bijega, bili su zvjerski ubijani i u manjim ili većim skupinama (na desetke pa i stotine ljudi). Na taj način u jasenovačkom logoru stvarno je stradalo nekoliko (vjerojatno između tri i četiri) desetaka tisuća zarobljenika, ponajviše Cigana, pa Židova i Srba, a i Hrvata. Uvjeren sam da se taj broj može i točno utvrditi - osim možda za Ciga-

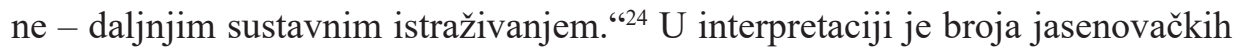
žrtava Tuđman napravio stanovit odmak od vremena kad ih je plasirao 1965. i kad je ustvrdio da je bilo oko 60.000 žrtava. Koristeći se rezultatima popisa iz 1964. godine, Franjo Tuđman, u to doba na čelu Instituta za historiju radničkog pokreta Hrvatske, izradio je 20. listopada 1965. elaborat koji je uputio Komisiji

23 TUDJMAN 1996: 232.

24 TUĐMAN 1989: 316; TUDJMAN 1996: 233. 
za historiju CK SKH, a koji je u sažetoj formi dospio do generala JNA i saveznog ministra obrane Ivana Gošnjaka i predsjednika SFRJ Josipa Broza Tita. Prema podacima iz „Popisa žrtava rata 1941-1945“ koje je dobio od Republičkog zavoda za statistiku i koji su bili sumirani, a trebali su biti objavljeni u cjelini za SFRJ, „ukupne žrtve s teritorije SRH poginulih u NOB-u iznose 185.327 a od toga je stradalo u logorima zatvorima i deportacijama ukupno 59.639 (od toga u samim logorima 51.534)““. ${ }^{25}$ Nakon što su sistematizirani, rezultati toga popisa stavljeni su pod embargo, a Tuđmanu je tada, nakon što je objavio te podatke, odmjerena kazna u trajanju od tri godine, kako je navedeno ,zbog krivičnog djela neprijateljske propagande. ${ }^{\text {“26 }}$ Tim je povodom Vjesnik objavio detalje o toj Tuđmanovoj inkriminaciji, navodeći kako je „u intervjuu s izvjesnim Vladimirom Markovićem koji je objavljen u ustaškom emigrantskom listu Hrvatska država u kolovozu 1978. Tuđman uz ostalo izjavio: 'Po sigurnim i pouzdanim statistikama u svim logorima u Hrvatskoj za vrijeme rata pogubljeno je 59.639 ljudi, ${ }^{27} \mathrm{i}$ to kako Srba tako i Hrvata, Jevreja, Cigana i drugih antifašista. ${ }^{28}$ To je ogroman i užasan broj i zločin; da je pobijeno šest ili šezdeset bilo bi ogromno i užasno. Ali ja sam protiv toga da se ovaj broj udesetorostručuje samo za Jasenovac na 600.000 ljudi'.“29

Tuđmanova se Bespuća često tematizira i u stranoj literaturi kad je riječ hrvatskom revizionizmu, napose u dijelu u kojemu se elaborira uloga Židova u ustaškom logoru Jasenovac, a i zbog broja žrtava u njemu. Antropolog Robert M. Hayden, profesor iz Pittsburgha, analizirao je Tuđmanovu ulogu u razdoblju uoči raspada SFRJ i neposredno nakon toga te mu predbacio da umanjuje broj jasenovačkih žrtava do te mjere kako bi dokazao da „genocida nije bilo“, osim samo „nekoliko tijela“, pa da „stoga nema razloga za ispriku.““泩 U slojevitoj polemici koju je razvio s hrvatskim povjesničarom Ljubom Bobanom, naslovljenoj

25 KLJAKIĆ 1990a: 10.

26 Franji Tuđmanu tri godine zatvora, Vjesnik, 21. veljače 1981., 12.

27 TUĐMAN 1989: 54. Tuđman je osuđen na tri godine zatvora i pet godina zabrane javne i izdavačke djelatnosti. „Glavni i jedini crimen za 'neprijateljsku propagandu' bila je moja tvrdnja da u Jasenovcu nije ubijeno 700.000 ljudi, a izjava gen. Kajića koji je dostavio te podatke i napisao ih svojom rukom, i službeni statistički podatci nisu uopće uzeti u obzir, jer da ja s njima manipuliram, ne priznajući općepoznate u Vojnoj enciklopediji utvrđene žrtve.“ (TUĐMAN 1989: 54, bilješka na dnu).

TUĐMAN 1989: 54, $57 \mathrm{i}$ dr.

29 LUGAR 1981: 19. O intervjuu Tuđman kaže da je „tobožnji“ intervju koji su dali tiskati u najekstremnijem emigrantskom listu Hrvatska država. TUĐMAN 1989: 75. U razgovoru za Politikin svet Tuđman je ponovio svoj stav te usporedio četnički i ustaški pokret i zaključio kako su u svojim programima i zlodjelima slični. Podvukao je kako ,govoriti samo o Jasenovcu i na tome graditi teze o genocidnosti svakog hrvatstva, od Starčevića, Štrosmajera, Trumbića do današnjih dana je povijesno, politički užasno, i to je ono što u Hrvatskoj rađa nepovjerenje i zabrinutost." Vidi ŠTULA 1989: 25. 
Balancing Discussion of Jasenovac and the Manipulation of History ${ }^{31}$ Hayden osporava uravnoteženost Bobanove analize te opovrgava postojanje kritičke evaluacije izvora koji podupiru niže brojke žrtava ljudskih gubitaka u Drugom svjetskom ratu i žrtava Jasenovca. U svojoj je replici Hayden uglavnom usmjeren na formiranje slike o Tuđmanu te podvrgava kritici hrvatski nacionalizam. Povod je takvoj kritici složenica, jasenovački mit“ koju Tuđman rabi u svojoj knjizi, a Hayden uvjerava kako referiranje na Jasenovac kao „mit“ reflektira „zapanjujuće neuvažavanje osjećaja Srba (za koje je Jasenovac sve samo ne mit) te nije samo pogrdno vrijeđanje nego je zloslutno i prijeteće.“ Tuđmanovim argumentima o broju jasenovačkih žrtava Hayden suprotstavlja tvrdnju kako je broj žrtava važan kao „dokaz genocida“, a iz Bobanova navoda kako su ,ustaše ubijali i druge, ne samo Srbe“ Hayden zaključuje kako je „doista užas Jasenovca bio veći no što su neki srpski autori to istaknuli“", a Bobanovi kritički osvrti služe samo zato da „zamaskiraju još veći užas.“32

Iako dopušta da su Boban i Tuđman u vezi s brojem žrtava možda u pravu, čini se da Hayden ne opravdava artikuliranje takvog diskursa jer bi to umanjilo količinu zla koje je simbolizirano jasenovačkim žrtvama. Premda se referira na Bobanov tekst, stječe se dojam kako Hayden problem postavlja tako da posve ignorira Bobanove navode te u nastojanju zadržavanja pune simbolike stradanja Srba označene visokim brojevima jasenovačkih žrtava zanemaruje opširniji povijesni kontekst srpsko-hrvatskih odnosa koji je dao Boban. Usuprot trenutku u kojemu je njegova analiza objavljena (godina 1992.) i agresiji na Hrvatsku koju Hayden i ne spominje, on zaključuje kako nastojanjem da se ,umanje strahote fašističke NDH 1941-1945, Tuđman nije dao Srbima nikakvog razloga da žele ostati u nacionalističkoj državi“ “. ${ }^{33}$ Uporište takvoj tvrdnji Hayden nalazi u govoru akademika Jovana Raškovića iz svibnja 1991. u kojemu, među ostalim, Rašković kaže kako je „pokušaj minimiziranja ili skrivanja genocida nemoralan“ te su ga „Srbi u Hrvatskoj razumjeli kao poziv da se još jednom ponovi.“" ${ }^{43}$

Naposljetku, Hayden sugerira kako se pitanje Jasenovca i manipulacije povijesti valja preformulirati tako da se pitanje broja žrtava tretira u području znanstvenih tema, a njihovu se značenju ne može pristupati kroz srpski i hrvatski nacionalizam. „Napuhivanje jasenovačkih žrtava je pretjeranost srpskog nacionalizma kako bi pokazali navodno genocidnu narav Hrvata, ali mora biti uravnoteženo spoznajom da je Jasenovac tvorevina isključivo hrvatske nacionalističke ideologije koja se održala kratko, ali je bila brutalna u hrvatskoj državi 1940." Završavajući svoje

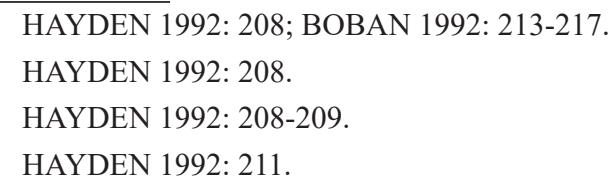

HAYDEN 1992: 208; BOBAN 1992: 213-217.

HAYDEN 1992: 208.

HAYDEN 1992: 208-209.

HAYDEN 1992: 211. 
izlaganje, Hayden ustvrđuje kako „rasprava o Jasenovcu i genocidnoj praksi NDH može poslužiti kao sramotna lekcija do koje je dubine intelektualni govor u Jugoslaviji potonuo pod razornim valovima nacionalizama koji su preplavili Jugoslaviju 1990/1991.“ Nisu samo nacionalizmi uporište Haydenovu gledištu o građanskom ratu koji se dogodio u Hrvatskoj u srpnju 1991., nego je on i posljedica „volje vlada Srbije i Hrvatske te pripremljene propagandne kampanje koja je poticala mržnju između Srba i Hrvata. ${ }^{\text {" }} 5$ Za dio te ratne propagande, smatra on, odgovorni su revizionistički povjesničari koji propituju masakre tijekom i nakon Drugog svjetskog rata i hrvatski publicisti koji niječu genocid u NDH te neki srpski intelektualci koji napuhuju broj žrtava. Tako postoje dva tabora: Hrvati koji poriču svoju ulogu i Srbi koji naglašavaju Jasenovac i NDH kao jedinstvenu Golgotu srpskog naroda. ${ }^{36}$ Godine 1993., odgovarajući na kritički osvrt Ante Kneževića koji se odnosi na polemiku Bobana i Haydena, Hayden je precizirao zašto je rat u Hrvatskoj 1991. okarakterizirao kao građanski. Naime, on objašnjava da u vrijeme kad je rat počeo, Hrvatska nije bila međunarodno priznata pa je po definiciji rat koji se vodi u jednoj državi građanski rat. ${ }^{37}$

Prema nekim sudovima, i sama je Tuđmanova politika vodila rehabilitaciji NDH. U vrijeme sve izglednijeg raskola SFRJ i agresivnog srpskog nacionalizma, odbacivanja slovenskog i hrvatskog prijedloga labave federacije, a potom konfederacije Hrvatska je raspisala višestranačke izbore na kojima je pobijedila Hrvatska demokratska zajednica s Tuđmanom na čelu. U atmosferi homogenizacije na Prvom općem saboru HDZ-a, 25. veljače 1990., predstavljen je program te stranke, „Programske zasade i ciljevi HDZ-a“, a podvrgnut je kritici dio Tuđmanova govora koji se tiče konteksta NDH. Tuđman je naglasio kako „NDH nije bila samo puka 'kvislinška' tvorba i ‘fašistički zločin' već i izraz kako političkih težnji hrvatskog naroda za svojom samostalnom državom tako i spoznaja međunarodnih čimbenika (... $)^{\text {‘38. }}$. U ostatku toga govora razvidno je kako Tuđman hrvatski državni suverenitet vezuje za antifašističke temelje, a govori i o pravima Srba u Hrvatskoj, ali je ova njegova izjava povezana s NDH potaknula lavinu napisa i neusklađenih interpretacija povjesničara i publicista te ga negativno okarakterizirala. Hrvatski historiografski revizionizam povjesničar Ivo Goldstein u knjizi Holokaust u Zagrebu obrazlaže „historiografskom retardacijom i društveno-političkom anomalijom“, a njezina je magistralna linija „fetišizam države

35 HAYDEN 1992: 212.

36 Isto.

37 HAYDEN 1993: 580.

38 Vidi Govor Franje Tuđmana na I. općem saboru Hrvatske demokratske zajednice, Zagreb, 24. veljače 1990., http://free-zg.t-com.hr/zdeslav-milas/FT/ft-03.htm; https://hr.wikisource. org/wiki/Govor_Franje_Tu\%C4\%91mana_na_I._Op\%C4\%87em_saboru_HDZ-a_24. velja\%C4\%8De_1990. 
i fetišizacija hrvatske državotvorne ideje“. Goldstein zamjera Tuđmanu da je tom izjavom dao impuls utjecaju ekstremne emigracije, ne smatrajući pritom samu stranku ustaškom. Hayden je, razmatrajući izborni zakon HDZ-a, povukao paralelu između državnih simbola koje je „HDZ-ova vlada ustanovila u junu 1990.“ i NDH pod kojima su ,pobijene stotine tisuća Srba za vreme Drugog svetskog rata“, pa je tako uz ,zapanjujuću neosetljivost prema osetljivosti Srba iz Hrvatske... HDZ-ova vlada otuđila Srbe iz Hrvatske. ${ }^{\text {" }} 9$ Nakon izbora Tuđmana za predsjednika Republike Hrvatske Hayden postavlja tezu o nacionalizmu široke osnove, odnosno nacionalizam pripisuje cijelom hrvatskom narodu. „Naravno, činjenica da je on 1990. godine od disidentskog nacionalističkog intelektualca postao nacionalistički predsednik Hrvatske koga je izabrao narod, da je ponovo bio izabran 1992, daje njegovim idejama o nacionalizmu posebnu uverljivost kao zvaničnom

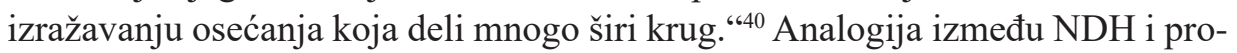
glašenja neovisne Republike Hrvatske 1991. u srpskom je tisku protumačena kao „,nacionalistička euforija, kontinuitet stare ideologije koja traži nezavisnu državu Hrvatsku. “41 Tu je Tuđmanovu izjavu Politika pretvorila u „uvjerljiv dokaz da je jedan od temeljnih političkih oslonaca HDZ-a ideologija Ante Pavelića“ te da „Franjo Tuđman želi postati novi ‘poglavnik’ nove Nezavisne države Hrvatske.“42

U inauguraciji revizionizma u Hrvatskoj mjerljiv su utjecaj imali i emigranti povratnici refleksijama na kontroverzne teme iz Drugog svjetskog rata. Jedan je od njih Ivo Omrčanin, povjesničar i teolog, koji nakon povratka iz emigracije 1989. u razgovoru za Slobodni tjednik daje svoju verziju Jasenovca i broja žrtava. ${ }^{43}$ Autor se poglavito bavio temama koje se tiču hrvatske povijesti, a među ostalima napisao je knjige Hrvatska 1941, 1942, 1943, 1944 i 1945. ${ }^{44}$ U uvodnom dijelu tiskanog razgovora, o Omrčaninu je navedeno kako je „18. travnja 1941. bio imenovan za prvog činovnika Ministarstva vanjskih poslova, posredovao je u pregovorima oko povratka krstionice kralja Višeslava u NDH. Imenovan je

HAYDEN 2003: 87-89.

40 HAYDEN 2003: 92.

41 SIMONOVIĆ 1990: 15.

42 DAVIDOVIĆ 1990: 15; ŽAKULA 1990: 15; Ko je Franjo Tuđman, Politika, 2. ožujka 1990: 6; SMILJANIĆ 1990: 17; ĐURIĆ 1990: 7; VUČELIĆ 1990: 17.

43 LUBUROVIĆ 1990: 6, 7. Hrvatska tiskovina Slobodni tjednik ili ST izlazila je od početka 1990. do 1993. godine.

44 Omrčaninova knjiga Hrvatska 1941 tiskana je u Zagrebu 1989. u autorovoj nakladi. Knjige Hrvatska 1942 i Hrvatska 1943 nose katalošku oznaku godine [1990.?], mjesto je izdanja Zagreb, a kao izdavač naveden je autor, prof. Ivo Omrčanin, međutim autor je na kraju knjige Hrvatska 1943 dodao opasku: „Dovršeno u Washingtonu 04.01.1990. Dan mojega povratka u Predgrađe. Od 1. rujna 1989 do 4. siječnja 1990. su izašle ove moje knjige: Hrvatska 19411 i 2 svezak, Hrvatska 1942 i Hrvatska 1943." Knjige Hrvatska 1944, tiskana 1990., i Hrvatska 1945, tiskana 1991., objavljene su u Washingtonu u nakladi Ivor Pressa. 
1. rujna 1944. opunomoćenim ministrom i otpravnikom poslova u Berlinu ${ }^{45} \mathrm{a}$ 1. ožujka 1945. godine povjereno mu je da pregovara sa saveznicima o predaji ustaša i domobrana. Prof. Omrčanin je isposlovao ulaznu vizu za Antu Pavelića u Argentinu te bio glavnim svjedokom u procesu ekstradicije Andrije Artukovića u Los Angelesu. "Vezano za Jasenovac i ustaški režim u NDH, Omrčanin osporava postojanje zločina, preimenujući ih u „nepodopštine“. Blajburških je žrtava, prema Omrčaninu, „bilo 550 tisuća Hrvata“. ${ }^{46}$

\section{Interpretacijski okviri broja jasenovačkih žrtava}

Utjecaj srpskog nacionalizma može se identificirati kroz djelovanje Književnih novina ${ }^{47}$ i SANU koja je povezala Krestićevo poimanje hrvatstva kao „genetski genocidnog“, aktivnosti SPC-a i njegove književne produkcije (Atanasije Jevtić, Velikomučenički Jasenovac i Od Kosova do Jadovna), Miletićeve, Bulajićeve i Dedijerove megavolumenske produkcije o temi Jasenovca tendenciozno usmjeravanog u formuliranju velikosrpskog političkog programa. SANU je održavao znanstvena okupljanja najprije zato da bi ukazao na štetnost ,prešućivanja zločina genocida ili umanjivanja ili preuveličavanja broja žrtava“, a istodobno je upadljivo branio sakrosanktnost broja jasenovačkih žrtava.

Među protagonistima očuvanja ideološke brojke jasenovačkih žrtava Titov je biograf Vladimir Dedijer koji je zagovarao različite procjene. Godine 1953. ustvrdio je da je u ,Jasenovcu pobijeno više od 200 hiljada lica“, a trideset godina kasnije navodi da „,prema istraživanju istoričara Antuna Miletića ubijeno je između 480.000-800.000““ ${ }^{48}$ Rezimirajući različite inačice, Dedijer zaključuje kako se „u dosad objavljenim publikacijama, naučnim radovima i štampi na temu o koncentracionom logoru Jasenovac i Stara Gradiška te brojke se kreću od 480.000 do 900.000 pa i preko milion. U najviše slučajeva procene broja ubijenih u logoru Jasenovac se kreću oko 700.000, a u logoru Stara Gradiška oko 80.000،“499

Dedijerova knjiga u kojoj se bavi i procjenom broja jasenovačkih žrtava Vatikan $i$ Jasenovac na gotovo 800 stranica široko obuhvaća masovna ubojstva u ratu. Knjigu

45 Prema drugom izvoru, Omrčanin je doista došao u Berlin „u poslanstvo, u ljeto 1944. Došao je kao teklić, a ne kao 'designirani poslanik'“. Vidi JONJIĆ 2009a, http://www.tomislavjonjic. iz.hr/IV_blazekovic.html (posjet 28. 9. 2017).

46 LUBUROVIĆ 1990: 6, 7.

47 Književne novine časopis su Udruženja književnika Srbije, a pokrenute su 1948. kao službene novine Saveza književnika Jugoslavije te su potom prerasle u novine Udruženja književnika Srbije. Redakcija je lista u Beogradu na adresi Francuska 7. Sadržaj objavljenih napisa bio je ideološki obojen; pojedini su se brojevi zbog sadržaja zabranjivali, a urednici ili cijele redakcije smjenjivali. Vidi http://www.uksrbije.org.rs/srb/ casopisi/knjizevne-novine (posjet 29. 9. 2017). 
je Dedijer posvetio Antunu Miletiću, od kojega je preuzeo neke dijelove. U samoj najavi daje se naslutiti da knjiga obiluje dokumentima, a mnogi su od njih preuzeti od drugih autora, primjerice, od Viktora Novaka i Bogdana Krizmana. Sama knjiga Vatikan i Jasenovac u znanstvenim krugovima nije imala nekog odjeka, a manjkala je i znanstvena identifikacija dokumenata. U njoj na nekoliko mjesta upada u oči oznaka Arhiv Vladimira Dedijera kao adresa za neke dokumente kojih je i preslika nejasna. ${ }^{50}$ Dedijerovu je uratku zamjereno „odsustvo naučnog aparata u kome bi se dala objašnjenja za neke pojmove i ličnosti koji se spominju u dokumentima (...) a unio je i neka dokumenta koja ne bi mogla biti uvrštena u Zbirku“51 jer se tematski ne uklapaju. Dedijerovo nekritičko valoriziranje dokumenata i nepreciznost generirali su dvije optužnice protiv njega. ${ }^{52} \mathrm{U}$ raspravi s kardinalom Kuharićem oko broja žrtava je Dedijer suprotstavio dokumente nacističkoga glavešine Heinricha Himmlera (koje je u netočnoj formi preuzeo od Miletića), prema kojima je u Jasenovcu do 1942. pogubljeno između 650 i 700 tisuća žrtava. Pritom je Dedijer, odnosno Miletić previdio da sadržaj Himmlerova pisma ,ne spominje ni koncentracioni logor, a još manje Jasenovac". ${ }^{53}$ Jovan Mirković je u knjizi Objavljeni izvori zaključio da „možda Dedijer ne čita svoje priloge“. ${ }^{54}$

Dedijer je uz tekst o ,ustaškom pokolju nad Srbima“ u pravoslavnoj crkvi u Glini priložio fotografiju skupine ljudi u crkvenom ambijentu. Kao dokaz isti-

50 Isto, Faksimil Ministarske naredbe o mjesnoj nadležnosti pokretnog prijekog suda, 14. srpnja 1941. (Arhiv Vladimira Dedijera).

51 GLIŠIĆ 1987: 14.

52 Prema vlastitom iskazu, prvi put izveden je pred sud nakon knjige Vatikan i Jasenovac. Zbog nje bio je žestoko napadnut od strane Vatikana. Zato je poslao otvoreno pismo Vatikanu, odnosno tadašnjem papi Vojtili, u kojemu raspravlja o dvama pitanjima. Najprije, Dedijer ustvrđuje kako je, prema podacima do kojih je došla „Američka obavještajna služba, vidljivo da je Vatikan pomogao stoosamdesetorici ustaša, ratnih zločinaca da se prebace u Južnu Ameriku a među njima i Paveliću“. Drugo pitanje odnosilo se na javnu tvrdnju kardinala Kuharića, da je ,u Jasenovcu ubijeno samo 40 tisuća osoba“. Nakon toga je Kuharić dobio priliku ponoviti svoju tvrdnju u slovenskom Delu, dok je Dedijer u tom trenutku bio pozvan na Temeljni sud u Ljubljani. On je odbio otići na „taj sud jer ga ne priznaje - to je klerikalni sud i neostaljinistički.“ Prema Dedijerovu uvjerenju, ,nikada ni jedan sud u Ljubljani nije tužio niti jednog povjesničara zbog njegovih radova. Sudovi nisu mjerodavni za utvrđivanje povijesti." Možda je takvo Dedijerovo uvjerenje uvjetovalo njegov neprofesionalan odnos prema dokumentiranjima odnosnih tema. Dedijer je, prema vlastitoj dijagnozi, tada već bio „star i bolestan“ i nejasno mu je kako ga se može tužiti jer „sud ne podleže provjeri povijesnih istina“. Dedijer imputira Slovencima da su 1914., ,kao pokorni borci vjernosti habsburškom prijestolju prvi bacili poklik o genocidu protiv Srba“ kad su tražili da se „svi Srbi objese o vrbe.“ Prema Dedijeru, ,glavni inspirator mržnje prema Srbima i drugim narodima“ bio je Marko Natlačen, slovenski političar i ban Dravske banovine. Vidi Pismo Vladimira Dedijera, NIN, 23. srpnja 1989., 63, 64. Pismo je izdiktirano jednoj grupi članova Russelova suda iz Skandinavije.

53 MIRKOVIĆ 2000: 288.

54 MIRKOVIĆ 2000: 287, 288; MILETIĆ 1986: 720, 721. 
nitosti, navedeno je za odnosnu fotografiju da je iz arhiva Božidara Cerovskog, pomoćnika ustaškog ministra Andrije Artukovića. U idućem broju Politike Bogdan Dečermić ustvrđuje kako se fotografija odnosi na ,pravoslavnu crkvu u Dubici na Uni, a snimljena je 1941.-1942. g. Okupljena skupina na fotografiji jesu Srbi ali nisu strijeljani u toj crkvi nego su navodno odvedeni u Jasenovac. No, taj dio nije pouzdan“. Dečermić osporava fotografiju koju je priložio Dedijer jer je on sâm unuk protoprezbitera-stavrofora Stojana Savića koji je bio paroh dubički (u crkvi s fotografije) više od desetljeća i pol prije Drugog svjetskog rata. Paroh Savić bio je uhićen i nakratko zatočen u logoru, a potom protjeran u Srbiju zajedno s transportom Srba. Fotografiju je načinio Hrvat Toma, profesionalni fotograf koji je i sâm završio u Jasenovcu. ${ }^{55}$

Godine 1989. u tisku su objavljeni rezultati Komisije za popis žrtava rata SIV-a SFRJ iz 1964. godine, o kojemu se do tada šutjelo, a koji je izrađen poimenično kako bi se dokazao iznos koji je Jugoslavija zatražila od Njemačkoj na ime ratnih reparacija ${ }^{56}$ Ovo je pojačalo tematizaciju žrtava Drugog svjetskog rata i u sklopu toga srpskih žrtava u Jasenovcu. U to se vrijeme i učestalije rabilo priznanje Vladete Vučkovića, autora brojke od 1,706.000, demografskog gubitka preimenovanog u žrtve. ${ }^{57}$ Prigodom posjeta Srbiji 1990. Vučković je namjeravao pronaći studiju koju je radio 1947. kako bi jugoslavenskoj javnosti argumentirano izložio njezin nastanak. Smatrao je da se tako može ,skinuti mrlja zalijepljena mrtvima prije više od pola stoljeća jer se zvanična jugoslavenska politika poigrala s njima računajući na ratnu odštetu“. Vučković je pokušao doći do svoje studije u Saveznom zavodu za statistiku, ali su mu ondje obrazložili da je „najverojatnije uništena u vrijeme kada se arhiva zavoda selila u Inđiju“. Nakon nekoliko telefonskih razgovora i nastojanja da stupi „u vezu s nekim iz bivšeg kabineta Edvarda Kardelja, rečeno mu je da postoji arhiv druga Kardelja, ali... I odustao je. ${ }^{c 58}$ Do dokumenata nije mogao doći. O važnosti tog zadatka govori i podatak da su se Vučković i daktilografkinja koji su bili na izvoru podataka nalazili pod neprekidnom paskom dvojice policajaca u civilu koji su šutke pratili sve i uništavali indigo papire s kojih bi bilo moguće sve pročitati te sav ostali radni materijal.

S obzirom na to da su demografske studije pravnika i dugogodišnjeg srpskog emigranta Bogoljuba Kočovića te hrvatskog ekonomista i demografa Vladimira Žerjavića izašle u vrijeme neposredno pred raspad SFRJ, kad se u tisku kroz nacionalističku prizmu učestalo tematizirao Drugi svjetski rat i ustaški zločini, Milan Bulajić, bivši direktor Muzeja žrtava genocida u Beogradu, dao je nakon izlaska iz

55 DEČERMIĆ 1990: 25.

56 CVETKOVIĆ 2002: 481, 482; BOGOSAVLJEVIĆ 1995: 12, 13; BOGOSAVLJEVIĆ 1996: 159-170; KRUŠELJ I ZAGORAC 1989: 24, 25.

57 VUČKOVIĆ 1985: 2, 3; BOBAN 1989: 409-413; BULIĆ 1990: 26-28.

58 BULIĆ 1990: 28. 
tiska knjige Vladimira Žerjavića svoje viđenje spomenute studije. On je ukazivao kako je svrha studije ,da se odgovornost za zločine umanji. Žerjavićevom studijom pitanje je postavljeno tako da ostaje upitnost nad žrtvama u drugom svetskom ratu uopšte. Mi smo posle rata izlazili pred svet sa milion i 700 hiljada postradalih i na osnovu toga postavljali pitanje reparacije. ${ }^{59} \mathrm{Tu}$ se na neki način pokazivala i veličina te borbe: 305 hiljada boraca je poginulo, a sada se tvrdi da je 700 hiljada manje, što znači da se sve smanjuje u tom obimu - broj stvarnih žrtava, civilnog stanovništva, zločine genocida, broj žrtava po logorima." Bulajić problematizira Žerjavićeve procjene broja žrtava u Jasenovcu jer, navodi, ,po Žerjaviću je u svim logorima ubijeno 216 hiljada, a ako uzmete da je na teritoriji NDH bilo petnaestak logora, pa još toliko u Srbiji, Makedoniji i drugim delovima naše zemlje, što onda u ovim aktualnim diskusijama otpada na Jasenovac?"60 Ovakav stav Bulajić ponavlja i na znanstvenom skupu „Stradanja Jugoslovena u drugom svetskom ratu“ održanom u Jasenovcu od 25. do 27. listopada 1989., a i u drugim osvrtima vezanim za Žerjavićeve izračune. Pritom ih osnažuje tvrdnjama kako je „brojka 1.706.000 gubitaka života koja je podnesena Međunarodnoj reparacionoj komisiji u Parizu i Međunarodnom vojnom sudu u Nürnbergu službena procena naše države iza koje su stajali naši najviši rukovodioci i zato se ona mora respektirati." Potvrdu svojemu stajalištu Bulajić potkrepljuje izračunom dr. Volgelnika koji opravdava službenu procjenu za jasenovačke žrtve u rasponu od 700.000 do milijun. ${ }^{61}$ Referirajući se na Bulajićev navod kako je u Muzeju žrtava genocida do „oktobra 1997. godine uneto 77.730 imena“, Bogoljub Kočović je ovako reagirao: „Pošto nisam upoznat s metodologijom tog popisa ne mogu po pitanju istog da zauzmem neki stav. Ali mogu bar da postavim pitanje: posle koliko vremena je spisak dostigao taj broj?“62

U poglavlju „Reakcije na moju knjigu“ Žerjavić se osvrće na Bulajićeve komentare i izračune te iznosi kako je moguću njegovu procjenu o ubijenih 285.000 Srba u naseljima Bulajić ignorirao. Prema Žerjaviću, ,ubijanje u naseljima, naročito naočigled članova porodice, može smatrati jednako okrutnim, ali to valjda nije tako 'interesantno' kao ono u logoru.“ Žerjavić zaključuje kako Bulajić, a i „većina drugih pisaca koji pišu o teroru okupatora i ustaša na teritoriju ratne tvorevine NDH ima glavno usmjerenje na logor Jasenovac.“63 Mirko Peršen,

59 Prema Zoranu Janjetoviću s Instituta za modernu istoriju iz Beograda, zahtjev za reparaciju postavljen je na temelju 960.000 žrtava, i to najvećim dijelom pokojnih (243.478), što je bila bitna razlika u odnosu na ugovore s drugim zapadnim zemljama. Vidi JANJETOVIĆ 2005: 4, 6. Prema Vladimiru Žerjaviću, podaci popisa 1964. prezentirani su radi SR Njemačke za reparacije, ali ,nije poznato kada je i formalno popis ratnih žrtava iz 1964. učinjen državnom tajnom“, ŽERJAVIĆ 1992: 36.

ŽERJAVIĆ 1992: 23.

ŽERJAVIĆ 1992: 23-39.

62 KOČOVIĆ 1998: 145.

63 ŽERJAVIĆ 1992: 44. 
autor knjige Ustaški logori, Bulajićevoj je dvosveščanoj knjizi Ustaških zločina genocida uzeo u obzir „1704 stranica i pobrojao sve žrtve srpske nacionalnosti koje su tamo navedene" te došao do brojke od 197.023 žrtava koju je suprotstavio Bulajićevim izrijekom navedenih 700.000 žrtava, koliko je on zagovarao prema „iskazima preživjelih“ ${ }^{64}$ Sarajevski sociolog i historičar Radomir Bulatović, autor knjige Koncentracioni logor Jasenovac s posebnim osvrtom na Donju Gradinu, u svom je dvadesetogodišnjem istraživanju, koje je imenovao ,istorijsko-sociološkom i antropološkom studijom“, došao do brojke od 1,110.929 ubijenih samo u Jasenovcu. ${ }^{65}$ Ukupan je sadržaj Bulatovićeve knjige u sjeni toga podatka. U svojoj analizi on zaključuje da 1,110.929 žrtava ,teško će ko moći oboriti, a bilo bi dobro da nije tako“. Koristeći se iskazom trojice bivših logoraša, Bulatović je jednostavnom matematičkom operacijom množenja 600 ubijenih osoba dnevno $\mathrm{s}$ brojem dana postojanja logora, 1.348 , došao do brojke od 808.800 ubijenih, a u slučaju manjeg broja likvidacija u danu, Bulatović prihvaća brojku od 740.000. $\mathrm{Na}$ sličan je način došao i do brojke od 404.400 ubijenih u Gradini. U osvrtu na Bulatovićevu knjigu pravoslavnog klerika Jovana Ćulibrka navodi se kako su „kriteriji bili spušteni toliko da autor nije ocenjivao stepen pouzdanosti različitih izvora i nije primenjivao naučni aparat..."66

Godine 1986. jugoslavenska je Vlada trijumfalno objavila vijest o izručenju ustaškog ministra unutarnjih poslova Andrije Artukovića, a proces je kao službeni promatrač SANU pratio Milan Bulajić. ${ }^{67}$ Bulajić je također 1958. bio u ulozi predstavnika Jugoslavije pred američkim sudom koji je raspravljao o zahtjevu za izručenje Artukovića kao ratnog zločinca. Jugoslavija je nastojala povezati djelovanje Artukovića i njemačkog nacističkog dužnosnika Adolfa Eichmanna u zločinima počinjenim nad Židovima te je bila vrlo fokusirana na Artukovićev slučaj sve vrijeme dok je trajalo suđenje Eichmannu. ${ }^{68}$ Jugoslavenska je Vlada poslala zahtjev za ispitivanjem Eichmanna i utvrđivanjem moguće veze s Artukovićem, ali je Eichmann zanijekao poznanstvo s njim. Također je i Albert Vajs, predsjednik Saveza jevrejskih opština, koji je sudjelovao u izradi stručne studije za izručenje Artukovića, ispitivao Eichmanna u tom smislu. U medijima se upućivalo na Artukovićevu odgovornost za smrt 700 tisuća osoba u Jasenovcu, što su ponavljali i strani mediji koristeći se jugoslavenskim izvorima. Suđenje

\footnotetext{
64 ŽERJAVIĆ 1992: 27; PERŠEN 1990: 327; KOČOVIĆ 1998: 27.

65 BULATOVIĆ 1990: 413.

66 ĆULIBRK 2011: 94.

67 Za detaljnije analizu vidi JONJIĆ 2009b; TANJUG 1986. Prema izvještaju agencije AP-a, u članku naslova „Reagiranja u svijetu o izručenju, istrazi i početku suđenja Andriji Artukoviću“, o Artukovićevu su izručenju pisali mnogi listovi i televizijske mreže: New York Times, Chicago tribune, Los Angeles Times, ABC, CBS i drugi. AP agencija 1986: 5.

68 Lov na Eichmanna. Proces nacističkom genocidu 1961: 379-382.
} 
se Artukoviću u sljedeće dvije godine medijski vrlo pratilo, ali se u ishodu nije postiglo potvrđivanje genocidne politike $\mathrm{NDH}$, niti preslikavanje uloge Adolfa Eichmanna na jugoslavenski kontekst. Naposljetku je Artuković osuđen na smrt, ali ga se u procesu nije teretilo za genocid, nego za ratne zločine dvojbenih dokaza. To je u Srbiji izazvalo negodovanje i optužbe da se hrvatske vlasti ne žele suočiti s ustaškom prošlošću.

Neprikriven razlog koji navodi i sâm Milan Bulajić taj je što je njegova četverosveščana knjiga Ustaški zločin genocida i suđenje Andriji Artukoviću 1986. godine nastala kao reakcija na suđenje Andriji Artukoviću. ${ }^{69}$ Naime, za ,zločine koje nije počinio“ te kako se ne bi donio zaključak da je Artuković osuđen nevin, a „ustaških

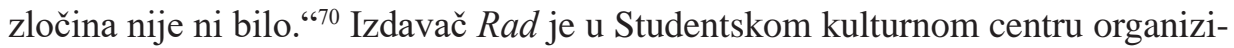
rao promociju Bulajićeve knjige. Tom je prigodom Bulajić istaknuo da 44 godine nakon oslobođenja još nije utvrđen broj (jasenovačkih) žrtava i to je razlog zašto se tim brojkama nerijetko najbezobraznije manipuliralo. Apostrofirao je prisutne „smetnje i poteškoće u prikupljanju ove građe iz ratnih godina 1941-1945.“ Stoga je, prema vlastitom priznanju, podnio prijavu Saveznom javnom tužiteljstvu protiv jugoslavenskog pravosuđa i pismeno se obratio SUBNOR-u, ali je ostao uskraćen za odgovor. Pored toga je za podizanje krivične prijave prikupio potpise „više od stotinu beogradskih odvjetnika protiv ključnog svjedoka u Artukovićevu suđenju, Bajre Avdića, tvrdeći da je sudjelovao u genocidu, da je počinio ratne zločine $\mathrm{i}$ lažno svjedočio na suđenju u Zagrebu. “"71 Avdić je ubijen za vrijeme rata u $\mathrm{BiH},{ }^{72}$ a Bulajić je ustvrdio da je povod njegovu ubojstvu bila knjiga o lažnom svjedoku koju je Artukovićev sin navodno napisao i dostavio američkoj Vladi.

Ova je Bulajićeva knjiga predstavljena i u Zagrebu početkom srpnja 1989. u Židovskoj općini, a domaćin skupa bio je tadašnji predsjednik ŽOZ, nedavno preminuli publicist Slavko Goldstein. Broju jasenovačkih žrtava koji je zagovarao Bulajić Slavko Goldstein je suprotstavio podatke iz knjige Vladimira Žerjavića Gubici stanovništva Jugoslavije u II svetskom ratu i okvirni zaključak da u ,Jasenovcu nije moglo biti ubijeno više od 110 hiljada ljudi“. Zbog Goldsteinova inzistiranja na tome „da za indicije moraju postojati dokazi“, a njih nitko ne navodi, imputirano mu je da je ,javno, na tribini čiji je domaćin, minimizirao žrtve rata u Jugoslaviji, a posebno u Hrvatskoj ne dopuštajući govor o ustaškim zločinima“" ${ }^{73} \mathrm{O}$ ovom je Bulajićevu obimnom djelu srpski povjesničar Veljko Đurić Mišina zabilježio kako je autor kvaliteti pretpostavio kvantiteta te ga

\footnotetext{
69 BULAJIĆ 1988; PETERMAN 1990: 24, 26.

70 ILIĆ 1989a: 14.

71 ILIĆ 1989b: 12.

72 Bajro Avdić nepokretan je, u invalidskim kolicima, ubijen u svojoj kući na 68. rođendan, 2. srpnja 1992. VELE 2011: 15.

73 SIMIĆ 1989: 52-54.
} 
zbog grešaka u knjizi atribuirao ,amaterizmom u istoriografiji“ “. ${ }^{74}$ Beogradski je profesor Vojin Dimitrijević Bulajićevu voluminoznu knjigu stavio u isti kontekst s propagandom Politikine rubrike „Odjeci i reagovanja“, koja je stvarala uvjerenje da je „Srbija stalno bila zapostavljana i da su Srbi od vajkada bili žrtve“. ${ }^{75}$ Prema Dimitrijeviću, Bulajić je svojom knjigom oprimjerio vrstu propagande koja se zbog nacističkih psiholoških djelovanja u Njemačkoj svrstava u Greuelpropagandu i predstavlja poznat način mobilizacije zasnovane na revanšizmu i obnavljanju mržnje. ${ }^{76}$

Paralelno sa suđenjem Artukoviću organizirana je pokretna izložba Spomenpodručja „Koncentracioni logor Jasenovac“, na kojoj su vojni povjesničar Antun Miletić i publicist Dragoje Lukić predstavili „više od tri stotine autentičnih fotografija i dokumenata o stradanjima u tom stratištu“, a „,izložba je prema planu trebala obići još pedesetak gradova u Jugoslaviji“. ${ }^{77}$ Cilj je predstavljanja bio pokazati kako otprije nametnuti broj jasenovačkih žrtava ne može biti obesnažen jer ima dokaz u dokumentima o ustaškim zločinima. ${ }^{78}$ Tom je prigodom prikazan i film Krv i pepeo Jasenovca redatelja Lordana Zafranovića.

U vrijeme suđenja Artukoviću u Oslobođenju je u seriji svjedočenja i napisa o Jasenovcu iznesen podatak kako „pod rasističkom parolom o čuvanju hrvatske nacije i stvaranju hrvatskog životnog prostora stavljeno je van zakona i bilo podvrgnuto istrebljenju i uništenju preko 1.900.000 Srba (likvidiranjem, iseljenjem i pokrštavanjem), 40.000 Židova i oko 40.000 Roma te komunisti i antifašisti Muslimani i Hrvati, odnosno oni koji su se suprotstavili okupatoru i ustaškom režimu."“79

44 Isto.

75 DIMITRIJEVIĆ 2004: 213, 214.

76 DIMITRIJEVIĆ 2004: 214.

77 ANDRIJIĆ 1986: 5; FRKOVIĆ 1986: 7.

78 U vrijeme dok se vodio proces protiv Artukovića, pojačane su aktivnosti kojima se pozornost europske i ondašnje jugoslavenske javnosti usmjeravala na Jasenovac, ,prezentacijom arhivske građe, fotografija, filmova u vojnim kolektivima, školama i sekcijama bivših logoraša, izdavanjem knjige pukovnika Antuna Miletića 'Koncentracioni logor Jasenovac 1941-1945', postavljanjem izložbe fotografija koja će obići pedesetak gradova Jugoslavije i otvaranjem zloglasne starogradiške 'Kule' za posjetioce“. U istom je tekstu Ana Požar, direktorica Spomen-područja, obrazložila kako ,širenje istine o strahotama jasenovačkog logora, u kojem je stradalo 700.000 nedužnih ljudi, uz naš rad, najviše pridonose članovi sekcija bivših logoraša Beograda, Banja Luke, Bihaća, Daruvara, Ljubljane, Karlovca, Mostara, Novog Sada, Prijedora, Rijeke, Sarajeva, Splita, Siska i drugih gradova.“ Navodi se i kako je „lani jasenovački kompleks obišlo 288.000, a ove se godine očekuje više od tristo tisuća posjetilaca,“ dok je filmove „Evanđelje zla“ i „Prah i pepeo Jasenovca vidjelo 3,7 milijuna posjetilaca iz zemlje i inozemstva“. FRKOVIĆ 1986: 7.

KNEŽIĆ 1986: 12. U Oslobođenju su u nastavcima od 4. do 17. travnja objavljeni članci iz edicije „Sarajevo u revoluciji - žrtve stradanja u Koncentracionim logorima“ skupine autora - Emerika Bluma, Fahrije Ajanovića, Borivoja Knežića i drugih. Blum je i sâm bio jasenovački logoraš, gdje je održavao električnu centralu. Uspio je pobjeći potkraj 1944. godine. Oslobođenje, 7. travnja 1986: 11 i Sjećanje: Emerik Blum, http://sarajevo.co.ba/sjecanje-emerik-blum/(posjet 29.4. 2012). 


\section{Otkopavanje jama sa žrtvama iz Drugog svjetskog rata}

Od početka osamdesetih godina Srpska pravoslavna crkva počela je aktivnije politički djelovati. Njezini predstavnici govore u javnosti o tada aktualnim događanjima na Kosovu i sve više prostora posvećuju stradanju Srba u NDH i Jasenovcu. U svojim su istupima pružali potporu oblikovanju srpskog identiteta i ujedinjenju Srba, a svoj su autoritet u SPC-u demonstrirali crnogorsko-primorski mitropolit Amfilohije Radović i episkop Atanasije Jevtić. Odbor SANU za izučavanje genocida povezao se sa SPC-om s kojim je 1990. organizirao akciju iskopavanja jama sa žrtvama iz Drugog svjetskog rata i stratišta u Hrvatskoj i BiH. Nakon Dedijerove smrti 1990., rad Odbora usmjeravali su Radovan Samardžić i Milan Bulajić, a dotadašnji su članovi izuzeti kao „neaktivni u radu Odbora.“ Umjesto njih, primljeni su neakademski građani Atanasije Jevtić, Srboljub Živanović, Đuro Zatezalo, Dragoje Lukić i drugi. Odbor je postao sredstvo za „borbu protiv politike organizovanog zaborava“" srpskog stradanja u NDH. ${ }^{80}$

Na redovitom je zasjedanju Arhijerejskog sabora u svibnju 1990. SPC zatražio od ,nadležnih državnih tijela da se omogući vađenje iz jama u toku rata pobijenih i njihovo dostojanstveno sahranjivanje pri hramovima i drugim za to pogodnim mjestima. “81 Sveti arhijerejski sabor smatrao je da je „krajnje vrijeme da se ispuni taj elementaran dug čovječnosti i prema nevino pobijenim u toku i poslije Drugog svjetskog rata, nastradalim u bratoubilačkom istrebljenju, jer bez mira sa mrtvima i među mrtvima nema i ne može biti mira ni pomirenja sa živima.“ Zahtjev je ponovljen u dvama navratima na izvanrednom zasjedanju Sabora u prosincu 1990. i redovitom zasjedanju u svibnju 1991. Za održavanje je prvog redovitog zasjedanja crkvenog sabora od 9. do 24. svibnja 1991. SPC odabrala Jasenovac, a ne Beograd, kao što je bilo uobičajeno. Tom je prigodom patrijarh Pavle, obilježavajući pedeset godina stradanja srpske Crkve i srpskog naroda za vrijeme rata u Hrvatskoj, retorički naveo kako nije namjera da se „podstiče krv i osveta nego da se sagledavanjem istine o zlu izbavi od novih zala““ ${ }^{82}$ Percepcija ove liturgije u Hrvatskoj doživljena je kao otvaranje starih rana te proširivanje odgovornosti za ustaške zločine na cijeli hrvatski narod.

Vađenje kostiju preraslo je u predstavu o čemu su izvješćivali i televizijski novinari i tisak. Pravoslavlje je napisom Mučenici na vidjelu dana uprizorilo detaljan opis vađenja kostiju iz hercegovačkih jama, dok je Politika intenzivirala govor o srpskom stradanju u NDH kako bi o ,ustaškom genocidu“ i ,zvjerstvima“ mogao čuti „,cijeli svijet“, koji inače i ,ne može povjerovati da se tako nešto

$80 \quad$ KLJAKIĆ 1992: 512.

81 JAHURA 1990: 8; HADŽI ANTIĆ 1990: 1-3.

82 TOMANIĆ 2001: 40, 43. 
moglo dogoditi““ ${ }^{83}$ Politikini izvještaji o otkopavanju jama iz Drugog svjetskog rata protegnuli su se i na 1991. godinu, inspirirani oživljavanjem najgorih sjećanja na Drugi svjetski rat. „Golem je to, veliki narod čije je i carstvo nebesko i Zemlja koja ga nije mogla progutati ni onda kada su krvoloci željeli Srbima ispuniti svekolike jame i bezdane zatirući genocidom srpstvo i pravoslavlje. I dok, mi Srbi, evo, duže od 600 godina vidovdansku tragediju i ponos čuvamo i njegujemo kao najplemenitiji događaj naše povijesti i svetosavske pravoslavne vjere... ne zaboravljamo milijunske mučenike koji punih 50 godina leže u paklima jama koje su im bile namijenili u NDH. Zlokobne 1941. više od jednog milijuna Srba pravoslavaca ubijeno je širom zloglasne NDH. Nikada i nitko do ljeta 1990. nije dopuštao Srbima da svoje zaklane pretke sahrane po kršćanskim kanonima i civilizacijskim običajima. Naprotiv, šutnjom, zataškavanjima i zabranama se je nastavljao započeti genocid (...). ${ }^{684} \mathrm{Na}$ akciju iskapanja kostiju iz jama, koju je inicirao SPC, osvrnuo se sredinom 1993. nekadašnji predsjednik Srpskog pokreta obnove, Vuk Drašković: „Onda su ti isti 'razumni' i 'umjereni' Srbi, odlučili zaviriti u jame. Tada sam se uplašio. Ne zbog svetkovina kraj jama (oni su to pretvorili u svetkovine, $u$ vašare) već zbog toga što sam znao tko su i kuda će ih, tako naglo posrbljene i tako naglo osokoljene njihova naglost odvesti. Nije, u tom 'preobražaju', bilo ničeg spontanog i sazrelog. Jednostavno, stizale su 'ozgo' i komande o nacionalnom interesu i sva popratna uputstva i oružja." Tako su na kraju, ,uz piće, pjesmu i igru pobijeni i protjerani Muslimani iz Trebinja, a njihove bogomolje porušene. “85

U međusobnoj polemici o temi žrtava Vjesnik i Politika / Politikin Svet uzimali su kao argumente s jedne strane Jazovku i Bleiburg, a s druge Jasenovac i Velebit. Nova hrvatska vlast dopustila je učestalije tematiziranje Bleiburga i drugih simbola ratnih zločina komunističkog režima. Politika je to protumačila kako „o odbrani hrvatske države i slobode gotovo da isto govore ustaše iz Blajburga i prvi čovek nove Hrvatske, koji sedi i u Predsedništvu SFRJ sve hoteći da ostvari preuređenje Jugoslavije prema novom 'sporazumu'. I aktualno i historijski, problem je sadržan u činjenici da je takva odbrana države i slobode dovela do Jasenovca“" ${ }^{86} \mathrm{U}$ povodu otkrivene jame „Jazovka“ dopredsjednik hrvatskog Sabora Stjepan Sulimanac rekao je kako „nije u Jasenovcu bilo najviše žrtava. Nakon rata bilo je 'udaranja' dan i noć. Poslije rata stradalo je najviše Hrvata. Čija je to bila genocidnost? Neka povijest na to odgovori“ ${ }^{87}$

\footnotetext{
83 ĐURICA 1990: 3.

84 NIKIĆ 1991: 13.

85 TOMANIĆ 2001: 151.

86 KLJAKIĆ 1990: 7, 8.

87 DMITROVIĆ 1990: 7; DŽADŽIĆ 1990a: 4-6; ŽANKO I ŠOLIĆ 1990: 99.
} 


\section{Jasenovac u ratnom kontekstu}

Neizbor Stjepana Mesića za predsjednika Predsjedništva SFRJ izazvao je reakciju Europske zajednice koja je u tročlanom sastavu 29. svibnja 1991. razgovarala s predstavnicima svih republika u Predsjedništvu. U svojoj knjizi, dnevniku Poslednji dani SFRJ, nekadašnji srbijanski član Predsjedništva SFRJ Borisav Jović dao je Mesićevo viđenje ukupnoga konteksta: „da bi se Hrvatska destabilizirala pokušava se uvjeriti svijet i domaća javnost da postoji sukob između Srba i Hrvata i da taj sukob može dovesti do građanskog rata što je apsolutna neistina. Naime, postoji sukob između hrvatske vlasti i militantnih grupa koje su u Hrvatskoj ali su instruirane, naoružane i financirane iz Srbije“ ${ }^{88}$ Borisav Jović iznio je svoje viđenje aktualne situacije: „Za vreme Drugog svetskog rata srpski narod je nastradao u Nezavisnoj Državi Hrvatskoj (u Hrvatskoj i Bosni i Hercegovini). Od skoro tri miliona ostalo je dva miliona stanovnika. To je u stalnom sećanju srpskoga naroda u Hrvatskoj i u Bosni i Hercegovini. Nacionalno pitanje u Jugoslaviji je rešeno na taj način da Jugoslavija garantuje sva građanska prava. Hrvatska je definisana kao država hrvatskog i srpskog naroda, a Bosna i Hercegovina kao država muslimanskog, srpskog i hrvatskog naroda. To su dvojne odnosno trojne države sa dva, odnosno tri naroda. Na višestranačkim izborima pobedila je u Hrvatskoj stranka koja je imala u svom programu osamostaljivanje Hrvatske kao posebne države. Nastao je vrlo ozbiljan problem za srpski narod u Hrvatskoj, a i u Bosni i Hercegovini, jer je rukovodstvo Bosne i Hercegovine izjavilo da, ako se Hrvatska odvoji, odvojiće se i ona od Jugoslavije. “89 Odgovornost za ovako postavljen problem Jović usmjerava na Jasenovac. „Imajući u vidu istorijsko iskustvo, klanje i masovno streljanje, samo na jednom mestu pobijeno je 700 hiljada ljudi, srpski narod je veoma uplašen od takve politike i aposlutno je ne može prihvatiti. Jer, on bi se našao u položaju nacionalne manjine u takvim, u tuđim državama, uveren je da bi ga vrlo brzo nestalo. I to je glavni uzrok problema. Čim je Hrvatska proglasila da se otcepljuje od Jugoslavije, srpski narod u Hrvatskoj je proglasio da se otcepljuje od Hrvatske - i nastali su međunacionalni sukobi. Moje je duboko uverenje da Jugoslavija ne može da se na taj način raspada - 'mirnim putem', jer je nemoguće naći pravu etničku granicu između naroda, pogotovu što Hrvatska ne prihvata bilo kakvu promenu granice. “"90

U ratnim uvjetima, u nekoliko mjeseci od travnja 1991., tadašnji pomoćnik ravnatelja Spomen-područja Jasenovac Simo Brdar i još dvojica njegovih kolega odnosili su dio po dio građe u (Kozarsku) Dubicu. Arhivska i muzejska građa,

\footnotetext{
88 „Pritisak Evropske zajednice da se izabere Mesić“, JOVIĆ 1991: 329.

89 JOVIĆ 1991: 330.

90 JOVIĆ 1991: 331, 332.
} 
inventurne knjige i mikrofilmovi 8. listopada 1991. odneseni su iz Spomen-područja Jasenovac u Banju Luku. UNESCO-ova je komisija u to vrijeme u dvama navratima obišla Spomen-područje Jasenovac i oba puta konstatirala sve veći manjak u odnosu na predratni fundus Muzeja. „S JNA smo ušli i uzeli sve što je preostalo“, kaže Simo Brdar. ${ }^{11}$ No, ta činjenica nije omela srpsko novinstvo i samoga Brdara da navede netočnu konstrukciju kako su „hrvatske paravojne formacije oružano napale Memorijalni centar ustaških logora genocida Jasenovac" ${ }^{\text {"92 }}$ te kako su ,pripadnici MUP-a i zbora narodne garde Hrvatske odneli 8.000 izloženih eksponata (...) koji su svedočili o stravičnom stradanju više od 700 hiljada nevine dece, žena i ljudi“993, pa je tada arhivska i muzejska građa prebačena u podrum Sime Brdara. ${ }^{44}$ Unatoč tomu, iznesene su tvrdnje da je minobacačkim projektilima potpuno uništeno ovo Spomen-područje, a da su granate „izbacile kosti i otkrile još jednu masovnu grobnicu“, dok su materijali, knjige, dokumenti i najvredniji muzejski eksponati uništeni, oštećeni ili odneseni. Takav je izvještaj upućen Kongresu svjetske federacije 20. listopada 1991. ${ }^{95}$ Premijer Republike Srpske Milorad Dodik tijekom prvog je mandata u razgovoru s direktorom beogradskog Muzeja žrtava genocida Bulajićem priopćio da je s najviše razine Republike Hrvatske postavljeno pitanje povrata ove građe koja je u srpskim krugovima proglašena „dobrom od izuzetnog značaja“. Vlasti Republike Srpske nisu bile voljne ukradenu zbirku vratiti Hrvatskoj, pa je tadašnji hrvatski ministar kulture Antun Vujić dogovorio s Američkim nacionalnim memorijalnim muzejom Holokausta (United States Holocaust Memorial Museum) u Washingtonu da zbirku ,prebaci na sigurno. ${ }^{“ 96}$ Osim toga, vošingtonski su muzeolozi izrazili želju da sami restauriraju i analiziraju izvornu jasenovačku građu te je s njima pisano dogovoreno da u roku od godinu dana zbirku preuzmu i vrate natrag u Hrvatsku. Milorad Dodik je kompletnu jasenovačku građu bespovratno i u tajnosti isporučio Muzeju holokausta u Washingtonu, pritom se uime Republike Srpske pisano odrekavši „,staranja i kontrole nad jasenovačkom građom u korist muzeja“. Svoj je potez kasnije pravdao motivacijom o „nemjerljivoj koristi za Srbe, jer će tako

\footnotetext{
91 GOVEDARICA 1990.

92 KESAR 1991: 3

93 Iz Muzeja Jasenovačkog Spomen kompleksa: Nestalo 8.000 eksponata, Dnevnik, 11. listopada 1991., 5; DEVETAK 1993: 6. S jasenovačkom građom Brdar je 1987. otvorio Dubički muzej.

94 Brdar je izjavio: „Moja kancelarija je uništena... u limenom sanduku nalazila se građa koju ja obrađujem. Sada je, eto, nema, a katanac na sanduku je presječen“. MARIĆ 1991: 11.

95 Memorandum Vlade Jugoslavije o zločinu genocida u Hrvatskoj i skrnavljenju Spomen-područja Jasenovac: Poziv na osudu genocida, Vojno-politički informator, br. 3 (331) (ožujak 1992.), 213, 214.

96 MILOSAVLJEVIĆ 2001, http://www.aimpress.ch/dyn/pubs/archive/data/200101/10110-004-pubs-zag.htm (posjet 10. 1. 2012); LEWIS 2001.
} 
svjetska javnost spoznati pravu istinu o njihovim stradanjima tijekom Drugog svjetskog rata." $" 97$

Otuđena je građa potkraj 2000. prebačena u Muzej holokausta u Washingtonu i potom vraćena u prosincu 2001. u matični muzej, ali nedostaje 30 posto građe i nije poznato gdje se ona nalazi. ${ }^{8}$ Spominje se pritom kako je Agencija Beta objavila vijest da je „Srpska pravoslavna crkva sačuvala više od polovine originalne muzejske zbirke Jasenovac - Donja Gradina i pohranila na sigurno mjesto u jedan od svojih manastira. Riječ je o najznačajnijem dijelu muzejske zbirke koja svjedoči o zločinima NDH nad Srbima, Židovima i Romima, tokom Drugog svjetskog rata u koncentracionim logorima Jasenovac i Donja Gradina. SPC je odlučila da spasi taj dio muzejske zbirke nakon saznanja da će premijer Republike Srpske Milorad Dodik potpisati sporazum o nepovratnom ustupanju zbirke tom muzeju, kao i da će zbirka preko Washingtona biti isporučena Hrvatskoj. Izvor je naveo da je crkva počela raditi na rekonstrukciji sačuvanog dijela muzejske zbirke Jasenovac - Donja Gradina. Nitko nije pojasnio kako je SPC došla do ove građe“. ${ }^{99}$

\section{Memorandumi Jugoslavije i SANU godine 1992.}

U knjizi Zločin je zločin prećutati objavljen je Memorandum o zločinu genocida u Hrvatskoj i skrnavljenju spomen-područja Jasenovac koji je Predsjedništvo SFRJ 31. siječnja 1992. uputilo predstavnicima međunarodnih institucija. U njemu je predloženo da UN utvrdi istinu o genocidnim postupcima hrvatske vlasti i da se taj zločin na odgovarajući način osudi. Dokument je upućen UN-u, KESS-u ${ }^{100}$, Europskoj uniji, veleposlanicima SAD-a, Kine, Francuske i Španjolske te brojnim drugim zemljama. Relevantan izvadak iz teksta Memoranduma glasi: „S osjećajem naglašene odgovornosti i zabrinutosti za daljnji razvoj događaja ne samo u Jugoslaviji, obavještavamo [gore navedene adresate], da su hrvatska tijela vlasti i njihovi paravojni i odmetnički oružani sastavi u toku 1991. i početkom 1992. drugi put u pola stoljeća izvršili zločin genocida nad srpskim narodom u Hrvatskoj i

97 USHMM 2001, http://www.ushmm.org/information/press/press-releases/croatian-wwii-concentration-camp-records-made-available-for-first-time-by-u (posjet 10. 1. 2012); BULAJIĆ 2001, http://www.jasenovac.org/news_read.php?nID=55 (posjet 10. 1.2012); BBC News 2001, http://news.bbc.co.uk/2/hi/programmes/from_our_own_correspondent/1673249.stm (posjet 11. 1. 2012).

98 ŠKILJAN 2005; [KRUŠELJ] 2001.

99 BULAJIĆ 2001, http://www.jasenovac.org/news_read.php?nID=55 (posjet 10. 1. 2012); MILOSAVLJEVIĆ 2001, http://www.aimpress.ch/dyn/pubs/archive/data/200101/10110-004-pubs-zag. htm (posjet 10. 1. 2012).

100 Konferencija za europsku sigurnost i suradnju, poznata i kao Konferencija za evropsku bezb(j) ednost i saradnju, 1994. prerasta okvire konferencije i postaje Organizacija za europsku sigurnost i suradnju, odnosno Organizacija za evropsku bezb(j)ednost i saradnju. 
druga teška krivična djela. Pored vršenja fizičke likvidacije pripadnika prije svega srpskog naroda (...) srpski narod u Hrvatskoj, od konstitutivnog, proglašen je nacionalnom manjinom, obespravljen i ponižen što čini osnovu sukoba u Hrvatskoj i Jugoslaviji. Činjenice koje se iznose u Aneksu I., II. i III. ovog memoranduma spadaju u primjere flagrantnog kršenja međunarodnog prava i to po međunarodnom pravu imaju karakter zločina genocida na osnovu Konvencije Generalne skupštine OUN iz 1948. (...) Ukazujemo također da je oskrnavljeno Spomen područje Jasenovac, koje obuhvaća prostor nekadašnjeg ustaškog logora (...) Polazeći od iznesenih činjenica jugoslavenska vlada smatra da postoji dovoljno elemenata da OUN i druge međunarodne organizacije identificiraju i kvalificiraju genocidne postupke koje čini hrvatska vlast (...) i istu osude. “U nastavku su još po točkama izneseni prijedlozi u kojima se traži osuda Hrvatske te formiranje povjerenstva koje bi utvrdilo razmjere oštećenja i skrnavljenja Spomen-područja Jasenovac. ${ }^{101}$

Predsjedništvo je tadašnje Jugoslavije u nekoliko navrata slalo predstavke visokim dužnosnicima međunarodne zajednice i UN-a. Tako je u predstavci datiranoj 10. travnja 1992. koju je potpisao tadašnji predsjednik Predsjedništva SFRJ Borisav Jović, a adresiranoj na UN, UN-ovu glavnom tajniku Boutrosu Boutros-Ghaliju upućen Memorandum Predsedništva o genocidnoj politici Hrvatske prema srpskom narodu u zapadnoj Slavoniji. U njemu je, među ostalim, navedeno kako se „fašistoidna, nacistička i genocidna politika hrvatskih vlasti prema srpskom narodu u administrativnim granicama Republike Hrvatske ponavlja posle pola veka.“102 Početkom kolovoza 1992. Odbor SANU za sakupljanje građe o genocidu protiv srpskog naroda i drugih naroda Jugoslavije u XX veku organizirao je s Državnom komisijom za ratne zločine i zločine genocida znanstveno savjetovanje $u$ Beogradu. Proizašle je materijale u svezak od 533 stranice sabrao Milan Bulajić, urednik je bio akademik Radovan Samardžić, a SANU je knjigu objavila sljedeće, 1993. godine. Knjiga je naslovljena Ratni zločini i zločini genocida 1991-1992, a u njoj je objavljen i Memorandum Vlade Jugoslavije o zločinima genocida u Hrvatskoj.

Sa stanovitim vremenskom odmakom srpski je povjesničar i specijalist za proučavanje genocida Jovan Mirković naveo neke propuste potonjeg Memoranduma koje je Milan Bulajić unio u izlaganje na Okruglom stolu 23. travnja 1996., održanom u Beogradu u organizaciji Muzeja žrtava genocida i beogradskog Instituta za savremenu historiju. U Mirkovićevu osvrtu sročenom kao Mišljenje o nekim nepreciznostima u Memorandumu Vlade Jugoslavije od 31.01.1992. o skrnavljenju spomen-područja Jasenovac ukazuje se na neke slabe strane Memoranduma nastale ,zbog podlijeganja medijskoj euforičnosti u službenim dokumentima,

101 MASLIĆ 1993: 131-149; Memorandum Vlade Jugoslavije o zločinu genocida u Hrvatskoj i skrnavljenju Spomen-područja Jasenovac: Poziv na osudu genocida, Vojno-politički informator, br. 3 (331) (ožujak 1992.), 213, 214.

102 MASLIĆ 1993: 178-189. 
čime se, ustvari, dovodi u situaciju, da zbog nepreciznih konstatacija, moguće je

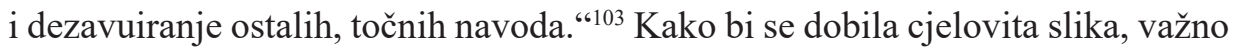
je znati da je u vrijeme kad je Vlada Jugoslavije slala na ugledne adrese pritužbu protiv Hrvatske, Spomen-područje Jasenovac već bilo ostalo bez svih eksponata i svi su se dokumenti nalazili u Republici Srpskoj u podrumu kuće bivšeg ravnatelja Sime Brdara.

\section{Primjer psihološkog utjecaja propagande: Dnevnik jedne tinejdžerice}

Od 1968. godine, kad je Spomen-područje Jasenovac službeno osnovano i otvoreno za javnost, događaji vezani za jasenovački logor obilježavaju se svake godine dvjema službenim komemoracijama u spomen na ustaške zločine nad Srbima, Židovima, Romima i hrvatskim antifašistima. Prva je komemoracija u povodu dana proboja logoraša 22. travnja, a drugom se obilježava Dan borca 4. srpnja. Komemoracija u povodu dana proboja logoraša tradicionalno je okupljala mladi naraštaj na „Sat povijesti“ koji „na najvećem groblju jugoslavenskih naroda... zauvijek optužuje ratne strahote i ustaški fašistički zločin i svjedoči o bezumnom svirepom mučenju i zvjerskom ubijanju ljudi.“104 Vodila se detaljna evidencija posjetitelja pa je, prema nekim podacima, Spomen-područje Jasenovac do 1986. posjetilo oko 4 milijuna posjetitelja, a od toga 80 posto mladih. ${ }^{105}$ Visok udio mladih dolazio je u organiziranim skupinama i bio u funkciji propisanog, uglavnom osmoškolskog obrazovnog usmjeravanja.

Uoči ratnog raspada SFRJ Jasenovac je postao sredstvom za raspirivanje mržnje i nasiln(ičk)og rješavanja razlaza: „historijska iskustva ilustriraju učinkovitost propagande i goleme štete koju ona može izazvati““. ${ }^{106}$ Dobar primjer za ilustraciju utjecaja propagande u ovom je kontekstu Dnevnik jedne tinejdžerice. ${ }^{107} \mathrm{U}$ tom je Dnevniku trinaestogodišnjakinje tinejdžerskim jezikom opisan učinak izložbe u Domu JNA 29. listopada 1990., koja je bila intermezzo u danima punim školskih ispita, dosadnih ili nenaučenih predmeta i jednog dečka kojega „nikako da izbije iz glave“. Usred toga stoji opis izložbe u sklopu predmeta iz povijesti: „Izložba je bila ubitačna. O logorima za vrijeme Drugog svjetskog rata: ljudska crijeva, glave, rebra, kosti. To su sve napravili ustaše. Gadovi! A kako je tek Ivica gledao

103 MIRKOVIĆ 2000: 113.

104 TANJUG 1987: 1, 6; FRKOVIĆ 1987: 3; DRAGIČEVIĆ I TAGIROV 1986: 2; FRKOVIĆ 1987: 3; Zločine ne zaboravljamo, Večernji list, 21. travnja 1987., 3.

105 HDA, kutija 240. Sabiranje materijala i podataka o Jasenovcu; ARSENIĆ 1986: 11; Jasenovac čeka status, Politika, 4. studenog 1986., 11.

106 DE LA BROSSE 2004: 127-213.

107 HMDCDR, Dnevnik M. P. 28.10.1990.-03.08.1995. kutija 1081/3 fond 2. pronađen u Vukovaru, gradivo RSK. 
onaj film o tome, kao da ništa ne vjeruje. Šonjo! Dabogda crko u najgorim mukama. Ustaša jedan!“‘. Drastičan zaokret zbog poistovjećivanja Hrvata s ustašama trinaestogodišnjeg je Ivicu u očima njegove vršnjakinje učinio odgovornim za ustaške zločine.

\section{Zaključno zapažanje}

Početkom se osamdesetih Jasenovcu pridaje izrazito politički predznak. Bez očiglednog odstupanja u interpretaciji jasenovačkog logora i srpski i hrvatski tisak do 1988. ustrajavaju na ,jugoslavenskom pogledu“ koji je broj jasenovačkih žrtava držao na uspostavljenim procjenama. U prilikama u kojima se našla SFRJ sredinom osamdesetih, promocija Jasenovca kao mjesta organiziranog zločina na kojemu je stradalo 700 tisuća do milijun Srba i potenciranje toga zločina kao zlodjela „genocidnih Hrvata“ te preklapanje s tezom da su Srbi uvijek bili ,zakinuti“, iako „zaslužni za stvaranje Jugoslavije“, Jasenovac je postao sredstvo za ubrzanu mobilizaciju srpstva. Srpske žrtve ubijene u jasenovačkom logoru jedna su od ključnih tema iz povijesti međusobnih hrvatsko-srpskih odnosa koju je, uz svijest o nužnom pijetetu, potrebno obrađivati na sasvim zreo, obestrašćen i znanstveno kritički način, lišen neprikladnog historiografskog i politiziranog pristupa iz vremena nametnute hegemonije.

\section{Bibliografija}

\section{Kratice}

$\mathrm{BiH}$ Bosna i Hercegovina

CK SKH Centralni komitet Saveza komunista Hrvatske

FNRJ Federativna Narodna Republika Jugoslavija

HDZ Hrvatska demokratska zajednica

HNB Hrvatska narodna banka

JNA Jugoslavenska narodna armija

KESS Konferencija za europsku sigurnost i suradnju

NDH Nezavisna Država Hrvatska

OUN Organizacija Ujedinjenih nacija

RSK Republika Srpska Krajina

SAD Sjedinjene Američke Države

SANU Srpska akademija nauka i umetnosti

SFRJ Socijalistička Federativna Republika Jugoslavija 


$\begin{array}{ll}\text { SIV } & \text { Savezno izvršno vijeće } \\ \text { SKH } & \text { Savez komunista Hrvatske } \\ \text { SPC } & \text { Srpska pravoslavna crkva } \\ \text { SUBNOR } & \text { Savez udruženja boraca Narodnooslobodilačkog rata Jugoslavije } \\ \text { UN } & \text { Ujedinjene nacije } \\ \text { USHMM } & \text { United States Holocaust Memorial Museum } \\ \text { ŽOZ } & \text { Židovska općina Zagreb }\end{array}$

\section{Arhivska građa}

HDA (Hrvatski državni arhiv), kutija 240. Sabiranje materijala i podataka o Jasenovcu.

HMDCDR (Hrvatski memorijalno-dokumentacijski centar Domovinskog rata), Dnevnik M.

P. 28. 10. 1990. - 03. 08. 1995. kutija 1081/3 fond 2. pronađen u Vukovaru, gradivo RSK.

\section{Izvori}

ANDRIJIĆ, L. 1986. Stradanja u Jasenovcu. Večernji list, 5. svibnja 1986., 5.

AP agencija. 1986. Reagiranja u svijetu o izručenju, istrazi i početku suđenja Andriji

Artukoviću. Večernji list, 14. travnja 1986., 5.

ARSENIĆ, Radoje. 1986. Jasenovac čeka status. Politika, 4. studenog 1986., 11.

BAČIĆ, Ivkica. 1989. Zašto šuti službena Srbija. Vjesnik, 23. rujna 1989., 3.

BEĆKOVIĆ, Matija. Ostatak zaklanog naroda. Književne novine, 15. rujna 1989., 3.

BULIĆ, Vanja. 1990. Gubici po želji druga Kardelja, Kad učitelji i inženjeri broje mrtve, Intervju s V. Vučkovićem. Politikin svet, br. 219, 5. rujna - 18. rujna 1990., 26-28.

ĆOSIĆ, Dobrica. 1989. Istina iz patnje. Književne novine, 15. rujna 1989., 1.

ĆURUVIJA, Slavko, Ivan STAMBOLIĆ. 2006. Žrtve: Ivan Stambolić Slavku Ćuruviji. Beograd: Udruženje Nauka i društvo Srbije.

DAVIDOVIĆ, Marko. 1990. Dostojan Pavelićev naslednik: Novi ‘poglavnik’ ne krije svoje namere. Politika, 1. ožujka 1990., 15.

DEČERMIĆ, Bogdan. 1990. Nije u Glini već u Dubici. Politika, 16. svibnja 1990., 23; Politika, 22. svibnja 1990., 25.

DEVETAK, N. 1993. Jasenovcu u pohode: Gradina - metropola mrtvih. Srpski glas, god. 4, br. 36, 1. listopada 1993., 6.

DMITROVIĆ, Ratko. 1990. Sjedinjenje kostiju koljača i žrtava. Politika, 7. srpnja 1990., 7.

DRAGIĆEVIĆ, Milena, Tatjana TAGIROV. 1986. Otvoren Okrugli stol 'Jasenovac 86', Pouka jasenovačkog pakla. Večernji list, 15. - 16. studenog 1986., 2.

DŽADŽIĆ, Petar. 1990a. Tuđmanova strategija. Politikin svet, 21. ožujka 1990., 4-6.

DŽADŽIĆ, Petar. 1990b. Istrgnuti listovi: o genocidnom narodu: Mi o dobrom divljaku. Politikin svet, 4. travnja - 2. svibnja 1990., 6, 7.

DŽADŽIĆ, Petar. 1990c. Nova ustaška država? Beograd: Politika, Izdavačka delatnost. 
ĐUKANOVIĆ, Aleksandar. 1986a. Ponuda beznađa. Večernje novosti, 24. rujna 1986., 2. ĐUKANOVIĆ, Aleksandar. 1986b. I AVNOJ je lažiran. Večernje novosti, 25. rujna 1986., 2.

ĐUKANOVIĆ, Aleksandar. 1989. Ponuda beznađa: I AVNOJ je lažiran. Duga, vanredni broj, lipanj 1989., 48, 49.

ĐUKIĆ, Đuro. 1994. Grobovi kao državna tajna. Srpski glas, 28. travnja 1994., 3.

ĐURICA, B. 1990. Ustaše su ubijale i novorođenčad. Politika, 22. studeni 1990., 13.

ĐURIĆ, Miodrag. 1990. Tuđman priziva NDH. Politika, 26. veljače 1990., 7.

Franji Tuđmanu tri godine zatvora. Vjesnik, 21. veljače 1981., 12.

FRKOVIĆ, J. 1986. Iza žice bio je užas. Večernji list, 7. svibnja 1986., 7.

FRKOVIĆ, J. 1987. Povijest ispisana žrtvama. Večernji list, 20. travnja 1987., 3.

GLIŠIĆ, Venceslav. 1987. Vatikan i Jasenovac. Politika, 14. studenog 1987., 14.

HADŽI ANTIĆ, Dragan. 1990. Saopštenje Svetog arhijerejskog sabora Srpske pravoslavne crkve. Pravoslavlje, br. 557, 1. lipnja 1990., 1-3.

Hrvatski sabor je donio Ukaz o proglašenju Zakona o utvrđivanju ratnih i poratnih žrtava II. svjetskog rata, Narodne novine, br. 53/A, 8. listopada 1991., 1343.

ILIĆ, Momir. 1989a. Mračne računice nad stratištima, razgovor s Milanom Bulajićem. Politika, 18. lipnja 1989., 14.

ILIĆ, Momir. 1989b. Da li će neko konačno odgovarati za genocid: Beogradski advokati optužuju krunskog svjedoka na suđenju Artukoviću. Politika, 11. lipnja 1989., 12.

Iz Muzeja Jasenovačkog Spomen kompleksa: Nestalo 8.000 eksponata. Dnevnik, 11. listopada 1991., 5.

JAHURA, Milenko. 1990. Stradanje Srba u NDH: srpski novomučenici u Hercegovini. Pravoslavlje, br. 567, 1. studenog 1990., 8.

Jasenovac - nemi svedok bezumlja, Tradicionalni susret mladih povodom 42. godišnjice proboja logoraša. Politika, 20. travnja 1987., 1, 6.

JEVTIĆ, Atanasije. 1995. Velikomučenički Jasenovac. Beograd-Valjevo: Glas crkve.

JOVANOVIĆ, Zoran. 1989. Ko sve pobedi, sve i uništi - intervju s Tanasijem Mladenovićem. Duga, 19. kolovoza - 2. rujna 1989., 14, 15.

JOVIĆ, Borisav. 1995. Poslednji dani SFRJ. Zapisi iz dnevnika B. Jovića. Beograd: Politika.

KAČAN, Ankica. 2000. Pregledi: Analiza inozemnog duga Republike Hrvatske. $H N B$, br. P-4 (listopad 2000.), 1.

KESAR, Jovan. 1991. Kako su Tuđmanovi bojovnici poharali Spomen područje Jasenovac - Ostao samo spisak. Novosti, 12. listopada 1991., 3.

KLJAKIĆ, Slobodan. 1990a. Uz inicijativu za osnivanje Muzeja žrtava genocida: I ćutanje o žrtvama je zločin - „Strogo poverljivi“ rezultati jednoga popisa. Politika, 19. srpnja 1990., 10.

KLJAKIĆ, Slobodan. 1990b. Kao da se Jasenovac nije dogodio. Politika, 7. srpnja 1990., 7,8 . 
KLJAKIĆ, Slobodan. 1992a. Zapisnik sa sednice Odbora za sakupljanje građe protiv genocida srpskog i drugih naroda Jugoslavije u XX. veku, 24. prosinca 1990. U KLJAKIĆ 1992b: 512.

KLJAKIĆ, Slobodan. 1992b. Kratka istorija Odbora SANU za sakupljanje građe o genocidu nad srpskim narodom i drugim narodima Jugoslavije u XX veku. Catena mundi II, prir. Predrag R. Dragić Kijuk, 498-515. Beograd-Kraljevo: Ibarske novosti, Matica Srba i iseljenika Srbije.

KNEŽIĆ, Borivoje. 1986. Zločin protiv čovjeka i civilizacije. Iz edicije Sarajevo u revoluciji grupe autora. Oslobođenje, 9. travnja 1986., 12.

Ko je Franjo Tuđman. Politika, 2. ožujka 1990., 6.

KRESTIĆ, Vasilije. 1986. O genezi genocida nad Srbima u NDH. Književne novine, god. XXXII, br. 716, 15. rujna 1986., 1, 4, 5.

KRESTIĆ, Vasilije. 1994. Iz istorije Srba i srpsko-hrvatskih odnosa. Beograd: BIGZ.

[KRUŠELJ, Željko]. 2001. Jasenovačka zbirka na putu u Hrvatsku. Večernji list, 29. studenoga 2001: 2. Dostupno na https:/www.vecernji.hr/vijesti/jasenovacka-zbirkana-putu-u-hrvatsku-704863 (posjet ostvaren 4. 10. 2017.).

KRUŠELJ, Željko, Đuro ZAGORAC. 1989. Sporna knjiga mrtvih. Aktualne kontroverze $\mathrm{u}$ istraživanju broja poginulih i umrlih Jugoslavena naprosto tjeraju na analizu zbivanja oko popisa iz 1964. godine. Danas, br. 405, 21. studenoga 1989., 24, 25.

LEWIS, A. Neil. 2001. Documenting a Death Camp in Nazi Croatia. New York Times, 14. studenog 2001.

Lov na Eichmanna. Proces nacističkom genocidu. 1961. Zagreb: NIP.

LUBUROVIĆ, Željko. 1990. Amerika financira Goldsteina. Interview - prof. Ivo Omrčanin viši opunomoćeni ministar (poslanik) i otpravnik poslova NDH u Berlinu. Slobodni tjednik, br. 3, 14. ožujka 1990., 6-7.

LUGAR, Ivan. 1981. 'Povijesne istine' po Franji Tuđmanu. Sedam dana, br. 15, Vjesnikov dodatak, 21. veljače 1981., 19.

LJUŠTIĆ, Radoš. 1989. Od jugoslovenstva do genocida. Politika, 28. siječnja 1989., 21.

MARIĆ, Milenko. 1991. Da li su kustosi iz Spomen-područja Jasenovac pre ratnih okršaja uspeli da sklone dragocena svedočanstva. Umesto humki minski krateri. Borba, 15. listopada 1991., 11.

MASLIĆ, Anđelko. 1993. Zločin je zločin prećutati: Izbor dokumenata najviših državnih organa Jugoslavije o ratnim zločinima genocida i drugim stradanjima srpskog naroda u Hrvatskoj i Bosni i Hercegovini (1991-1992). Novi Sad: IP Megilot, Srpska novinska agencija „Srna“, NIP - Polet.

Memorandum Vlade Jugoslavije o zločinu genocida u Hrvatskoj i skrnavljenju Spomenpodručja Jasenovac: Poziv na osudu genocida. Vojno-politički informator, br. 3 (331) (ožujak 1992.), 213, 214.

MILETIĆ, Antun. 1986. Koncentracioni logor Jasenovac 1941-1945. Knjiga II. Beograd: Dokumenta. 
MIRKOVIĆ, Jovan. 2000. Objavljeni izvori i literatura o jasenovačkim logorima. Laktaši-Beograd: GrafoMark, Muzej žrtava genocida.

Narodna banka Jugoslavije. Godišnji izveštaj. 1991. Beograd.

Narodne novine, br. 66, 7. lipnja 2002., 1127.

NEDIĆ, Jovan. 1990. Mučenici na videlu dana. Pravoslavlje, br. 569, 1. prosinca 1990., 3.

NIKIĆ, M. Dušan. 1991. Neispunjena obaveza. Politika, 11. siječnja 1991., 13.

Nova ustaška država? Politika, 17. listopada 1990., 40.

PETERMAN, Branislav. 1990. Istraživanje dr. Milan Bulajića: Ustaški 'tunel pacova'. Politikin svet, 30. svibnja 1990., 24; 12. lipnja 1990., 26.

Pismo Vladimira Dedijera. NIN, 23. srpnja 1989., 63, 64.

POPOVIĆ, Ratimir. 1989. Dugo je vođena politika štetna po interese Jugoslavije i Srbije. Politika, 12. ožujka 1989., 9.

Povijest ispisana žrtvama. Večernji list, 20. travnja 1987., 3.

PRERADOVIĆ, Ranko. 1986. Vječna opomena stradalništva. Oslobođenje, 21. travnja 1986., 3.

RAPAIĆ, Mirko. 1991. SANU o genocidu nad Srbima: Tragedija srpske djece. Riječ, list srpskog naroda Krajine, Ratno izdanje, br. 30-31, 29. studenog 1991., 21.

RAŠKOVIĆ, Jovan. 1990. Luda zemlja. Beograd: Akvarijus.

SIMIĆ, Dragoslav. 1989. Čudo u Zagrebu: Goldsteinov zid plača. Intervju, 21. srpnja 1989., 52-54.

SIMONOVIĆ, Đorđe. 1990. Fašizam na delu. Politika, 28. veljače 1990., 15.

SMILJANIĆ, R. 1990. Srbi neće da finansiraju Tuđmanovu NDH. Politika, 26. ožujka 1990., 17.

ŠARAC, Predrag. 1995. Sjednica Odbora za pripremu komemoracije. Graničar, br. 4, 14. travnja 1995., 5.

ŠEATOVIĆ, Nikola. 1994. Da se pamti i ne zaboravi. Iskra, 1. svibnja 1994., 1, 2.

ŠTULA, Mila. 1989. ,JJedno pitanje, jedan odgovor: Tuđman o Jasenovcu“, Politikin svet, br. 199, 29. studenog 1989., 25.

TANJUG. 1986. Izručen zločinac Andrija Artuković, kronologija jugoslavenskih zahtjeva, Pravda je pobjedila. Večernji list, 13. veljače 1986., 3, 4.

TANJUG. 1987. Jasenovac - nemi svedok bezumlja, Tradicionalni susret mladih povodom 42. godišnjice proboja logoraša. Politika, 20. travnja 1987., 1, 6.

TANJUG. 1990. Srbija neće dozvoliti rasprodaju svoje teritorije. Politika, 23. srpnja 1990., 7.

TANJUG. 1994. Nikad više u zajedničku državu. Srpski glas, 28. travnja 1994., 3.

VELE, Faruk. 2011. Ekshumiran krunski svjedok zločincu Andriji Artukoviću: Nepokretnog Bajru Avdića četnici su udavili vodom i krpama. Dnevni Avaz, 16. travnja 2011., 15.

VUČELIĆ, Milorad. 1986. Iskušenja krize. Književne novine, god. XXXII (prepravljeno XXVII), br. 719, 1. studenog 1986., 3, 4.

VUČELIĆ, Miodrag. 1990. Duh NDH. Politika, 26. veljače 1990., 17. 
VUČKOVIĆ, Vladeta. 1985. Žrtve rata. Sahrana jednog mita. Naša reč, br. 368 (listopad 1985.), 2, 3.

Zločine ne zaboravljamo. Večernji list, 21. travnja 1987., 3.

ŽAKULA, Jandre. 1990. Ustoličiše ‘Endehaziju' usred Zagreba, Šta čekaju državni organi. Politika, 1. ožujka 1990., 15.

ŽANKO, Želimir, Nikola ŠOLIĆ. 1990. Jazovka. Vjesnik, 6. srpnja 1990., 143.

\section{Elektronička dokumentacija}

BBC News. 2001. Croatian holocaust still stirs controversy, 29 November 2001. http:// news.bbc.co.uk/2/hi/programmes/from_our_own_correspondent/1673249.stm (posjet 11. 1. 2012).

BULAJIĆ, Milan. 2001. Afera tajne predaje građe Spomen područja Jasenovac iz Banje Luke u Vašington. Beograd, 27. siječnja 2001. http://www.jasenovac.org/news_read. php?nID=55 (posjet 10. 1. 2012).

GOVEDARICA, Slavka. 1999. Ostavljena da nestane. Reporter, br. 85, prosinac 1999. Izvor: Pravoslavno mitropolija crnogorsko primorska. http://www.mitropolija.me/stari /aktuelno/saopstenja/jasenovac_l.html (posjet 12.1.2012).

Govor Franje Tuđmana na I. općem saboru Hrvatske demokratske zajednice, Zagreb, 24. veljače 1990. http://free-zg.t-com.hr/zdeslav-milas/FT/ft-03.htm; https://hr.wikisource. org/wiki/Govor_Franje_Tu\%C4\%91mana_na_I._Op\%C4\%87em_saboru_HDZa_24._velja\%C4\% $\%$ De_1990. (posjet 4. 10. $201 \overline{1}$.).

JONJIĆ, Tomislav. 2009a. Razgovor s dr. Milanom Blažekovićem, „S optimizmom gledam u hrvatsku budućnost“. http://www.tomislavjonjic.iz.hr/IV_blazekovic.html (posjet 28. 9. 2017).

JONJIĆ, Tomislav. 2009b. Andrija Artuković je protuzakonito izručen i osuđen! U povodu knjige Christophera H. Pylea Extradition, Politics and Human Rights. 2001. Philadelphia: Temple University Press. http://www.tomislavjonjic.iz.hr/ V_10_artukovic. html (posjet 28. 9. 2011).

MILOSAVLJEVIĆ, Mladen. 2001. Ko je prodao jasenovačku građu. Banja Luka, 25. siječnja 2001. http://www.aimpress.ch/dyn/pubs/archive/data/200101/10110-004-pubszag.htm (posjet 10. 1. 2012).

Sjećanje: Emerik Blum. http://sarajevo.co.ba/sjecanje-emerik-blum/(posjet 29. 4. 2012).

United States Holocaust Memorial Museum. 2001. Croatian WWII Concentration Camp Records Made Available for First Time by United States of Holocaust Memorial Museum, press release, 13 November 2001. http:/www.ushmm.org/information/press/ press-releases/croatian-wwii-concentration-camp-records-made-available-for-firsttime-by-u (posjet 10. 1. 2012).

\section{Literatura}

BILANDŽIĆ, Dušan. 1999. Hrvatska moderna povijest. Zagreb: Golden marketing. BOBAN, Ljubo. 1989. Kontroverze iz povijesti Jugoslavije. Knjiga 2. Zagreb: Školska knjiga. 
BOBAN, Ljubo. 1990. Note and Comments: Jasenovac and the Manipulation of History. East European Politics and Societies 4: 580-592.

BOBAN, Ljubo. 1992. Still More Balance on Jasenovac and the Manipulation of History. East Europian Politics and Societies 6: 213-217.

BOGOSAVLJEVIĆ, Srđan. 1995. Drugi svetski rat - žrtve u Jugoslaviji. Republika, br. 117, 1. - 15. jula 1995., 12-13.

BOGOSAVLJEVIĆ, Srđan. 1996. Nerasvetljeni genocid. U Srpska strana rata. Trauma i katarza u istorijskom pamćenju 1. dio, ur. Nebojša Popov, 159-170. 2. izd. Beograd: Samzdat B92.

BULAJIĆ, Milan. 1988. Ustaški zločini genocida i suđenje Andriji Artukoviću 1986. godine. Knj. I-III. Beograd: Rad.

BULATOVIĆ, Radomir. 1990. Koncentracioni logor Jasenovac s posebnim osvrtom na Donju Gradinu. Sarajevo: Svetlost.

CVETKOVIĆ, Dragan. 2002. Stvarni gubici Hrvatske prema popisu „Žrtve rata 19411945. Iz 1964. godine“. Analiza trenutnog stanja prema do sada izvršenoj reviziji. U Dijalog povjesničara - istoričara Srbije i Hrvatske 5, ur. Igor Graovac, 481-503. Zagreb: Zaklada Friedrich Neumann.

ĆULIBRK, Jovan. 2011. Istoriografija holokausta u Jugoslaviji. Beograd: Institut za teološka istraživanja.

DEDIJER, Vladimir. 1953. Josip Broz Tito. Prilozi za biografiju. Knjiga 1. Zagreb: Kultura.

DEDIJER, Vladimir. 1981. Novi prilozi za biografiju Josipa Broza Tita. Knjiga 2. Zagreb: Mladost.

DEDIJER, Vladimir. 1987. Vatikan i Jasenovac. Beograd: Rad.

DE LA BROSSE, Renaud. 2004. Politička propaganda i projekt „Svi Srbi u jednoj državi“: posledice instrumentalizacije medija za ultranacionalističke svrhe. U Milošević vs. Jugoslavija, knjiga I, prir. Sonja Biserko [Biblioteka Svedočanstva, broj 20], 127-213. Beograd: Helsinški odbor za ljudska prava u Srbiji. Dostupno na http://www.helsinki. org.rs/doc/Svedocanstva20-1.pdf (posjet 18. 4. 2012).

DIMITRIJEVIĆ, Vojin. 2004. Srbija: u evropsku integraciju s teretom prošlosti? U Nasilno rasturanje Jugoslavije, uzroci, dinamika, posledice. Zbornik radova, ur. Miroslav Hadžić, 211-115. Beograd: Goragraf.

ĐURIĆ, Veljko. 2005. Neki problemi istraživanja istorije Srpske pravoslavne Crkve: Koliko amaterizam u istoriografiji /ne/doprinosi istraživanju sudbine jerarhije Srpske pravoslavne Crkve. U Genocid u 20. veku na prostorima jugoslovenskih zemalja. Zbornik radova, ur. Jovan Mirković, 477-489. Beograd: Institut za noviju istoriju Srbije.

Enciklopedija Jugoslavije. 1971. Sv. 8. Zagreb: Jugoslavenski leksikografski zavod.

GOLDSTEIN, Ivo. 2001. Holokaust u Zagrebu. Zagreb: Novi Liber.

HAYDEN, M. Robert. 1992. Balancing Discussion of Jasenovac and the Manipulation of History. East European Politics and Societies 6 (Spring 1992): 207-210.

HAYDEN, M. Robert. 1993. Notes and Comments On Unbalanced Criticism. East European Politics and Societies 7 (Fall 1993): 570-582. 
HAYDEN, M. Robert. 2003. Skice za podeljenu kuću. Ustavna logika jugoslovenskih sukoba. Beograd: Samizdat.

JANJETOVIĆ, Zoran. 2005. Pitanje odštete žrtvama nacizma u jugoslovensko-njemačkim odnosima posle Drugog svetskog rata. Društvo za srpsko-nemačku saradnju 1991: 1-9. Dostupno na http://www.drustvosns.org/nemacka\%20manjina/janjetovic/Z.\%20 Janjetovic, \%20Pitanje\%20odstete\%20zrtvama\%20nacizma\%20u\%20jugoslovenskonemackim\%20odnosima.pdf (posjet 12. 3. 2012).

JOVANOVIĆ, Jelka, Bojan TONČIĆ. 2002. Dokumenti o prošlosti: Odjeci i reagovanja (Politika 1988-1991), Okrugli sto Beograd 14-15. decembar 2001. Beograd: Fond za humanitarno pravo.

KANDIĆ, Ljubica. 1964. In Memoriam: Dr. Albert Vajs 1905-1964. Jugoslavenski istorijski časopis 2: 157, 158.

KOČOVIĆ, Bogoljub. 1998. Nauka, nacionalizam i propaganda: Između gubitaka i žrtava Drugog svetskog rata u Jugoslaviji. Pariz: Editions du Tutre.

KRIŽE, Željka. 2015. Velikosrpska politička propaganda uoči raspada Jugoslavije na primeru srbijanskoga tiska od donošenja Memoranduma SANU do početka ratnih sukoba u Hrvatskoj (1986-1991). Doktorska disertacija, Sveučilište u Zagrebu, Hrvatski studiji.

LEKIĆ, Slaviša, Zoran PAVIĆ. 2007. VIII sednica CK SK Srbije, Nulta tačka narodnog pokreta. Beograd: Službeni glasnik.

LUČIĆ, Ivo. 2003. Karađorđevo: politički mit ili dogovor?. Časopis za suvremenu povijest 35/1: 7-36.

MILOSAVLJEVIĆ, Olivera. 1995. Upotreba autoriteta nauke: Javna politička delatnost Srpske akademije nauka i umetnosti (1986-1992). Ogledi, Republika, 1. - 31. srpnja 1995., 1-54.

MIRKOVIĆ, Jovan. 2000. Jasenovačke žrtve. Beograd-Laktaši: Izdavač Muzej žrtava genocida, GrafoMark.

PERŠEN, Milan. 1990. Ustaški logori. Zagreb: Globus.

ŠKILJAN, Filip. 2005. Kolekcija filmskih i video zapisa Spomen područja Jasenovac s posebnim osvrtom na sjećanje logoraša. U Dijalog povjesničara - istoričara 10/2, ur. Igor Graovac, 309-324. Zagreb: Zaklada Friedrich Neumann.

TOMANIĆ, Milorad. 2001. Srpska crkva u ratu i ratovi u njoj. Beograd: Medijska knjižara krug.

TUDJMAN, Franjo. 1996. Horrors of the War: Historical Reality and Philosophy. New York: M. Evans \& Company.

TUĐMAN, Franjo. 1989. Bespuća. Zagreb: Nakladni zavod MH.

VAJS, Albert. 1957. The Crimes of the Faschist occupants and their Collaborators against Jews in Yugoslavia. Belgrade: Federation of Jewish Communities of the Federative People's Republic of Yugoslavia.

VEKARIĆ, Bruno (ur.). 2011. Reči i nedela. Pozivanje ili podsticanje na ratne zločine u medijima u Srbiji 1991-1992. Beograd: Centar za tranzicione procese. 
ŽERJAVIĆ, Vladimir. 1992. Opsesije i megalomanije oko Jasenovca i Bleiburga. Gubici stanovništva Jugoslavije u drugom svjetskom ratu. Zagreb: Globus.

\section{Jasenovac Victims and the Establishment of the National Programme in Serbia (1986-1995)}

The victims of World War II, and particularly the victims killed at the Jasenovac concentration camp, occupy an important place in Croatian and Serbian national memories, and they are still a sensitive subject of victimology studies in the region. Very early on, for the purposes of the Yugoslav ideology, the subject became a first-rate political issue and subject to manipulation and even abuse. This paper aims to reconstruct the creation of the propagandistic framework in which the victims of World War II and the Jasenovac victims were used in conflicting national narratives in the eve of the disintegration of Yugoslavia and during the war that followed. The reasons for the lasting debate in which the conflicting views on the common historical experience of Croats and Serbs came to fore, without contributing to a possible solution of the unresolved and burning issues, certainly lie in the complex nature of the problem itself. The possible causes may be found in the fact that journalism often assumed the role of historical research, and professional historians were frequently an instrument of propaganda.

Keywords: victims of World War II, Jasenovac victims, dissolution of SFRY, propaganda. Ključne riječi: žrtve Drugog svjetskog rata, jasenovačke žrtve, raspad SFRJ, propaganda.

Bernadica Jurić Franje Kulmera 7 HR-10373, Ivanja Reka berjur284@gmail.com 


\section{FILOZOFSKI FAKULTET SVEUČILIŠTA U ZAGREBU \\ ZAVOD ZA HRVATSKU POVIJEST \\ INSTITUTE OF CROATIAN HISTORY \\ INSTITUT FÜR KROATISCHE GESCHICHTE}

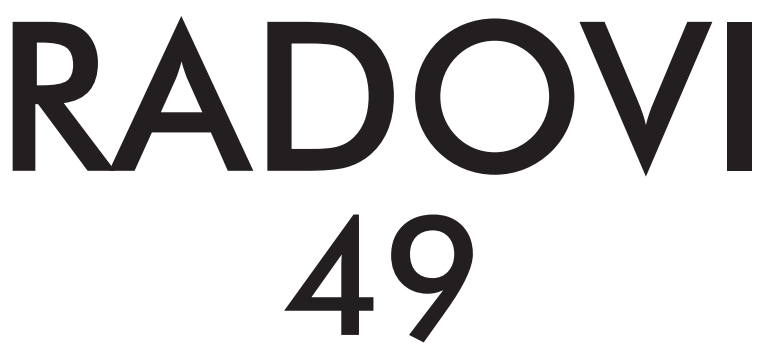

ZAVOD ZA HRVATSKU POVIJEST

FILOZOFSKOGA FAKULTETA SVEUČILIŠTA U ZAGREBU

\section{FF press}

ZAGREB 2017. 


\title{
RADOVI ZAVODA ZA HRVATSKU POVIJEST FILOZOFSKOGA FAKULTETA SVEUČILIŠTA U ZAGREBU \\ Knjiga 49
}

\author{
Izdavač / Publisher \\ Zavod za hrvatsku povijest \\ Filozofskoga fakulteta Sveučilišta u Zagrebu \\ FF-press \\ Za izdavača / For Publisher \\ Vesna Vlahović Štetić \\ Glavni urednik / Editor-in-Chief \\ Hrvoje Gračanin \\ Izvršna urednica / Executive Editor \\ Inga Vilogorac Brčić \\ Uredništvo / Editorial Board
}

Bruna Kuntić-Makvić (stara povijest/ancient history), Zrinka Nikolić Jakus (srednji vijek/

medieval history), Hrvoje Petrić (rani novi vijek/early modern history), Željko Holjevac (moderna povijest/modern history), Tvrtko Jakovina (suvremena povijest/contemporary history),

Silvija Pisk (mikrohistorija i zavičajna povijest/microhistory and local history),

Zrinka Blažević (teorija i metodologija povijesti/theory and methodology of history)

Međunarodno uredničko vijeće / International Editorial Council

Denis Alimov (Sankt Peterburg), Živko Andrijašević (Nikšić), Csaba Békés (Budapest), Rajko Bratož (Ljubljana), Snježana Buzov (Columbus, Ohio), Svetlozar Eldarov (Sofija), Toni Filiposki

(Skopje), Aleksandar Fotić (Beograd), Vladan Gavrilović (Novi Sad), Alojz Ivanišević (Wien),

Egidio Ivetić (Padova), Husnija Kamberović (Sarajevo), Karl Kaser (Graz),

Irina Ognyanova (Sofija), Géza Pálffy (Budapest), Ioan-Aurel Pop (Cluj),

Nade Proeva (Skopje), Alexios Savvides (Kalamata), Vlada Stanković (Beograd),

Ludwig Steindorff (Kiel), Peter Štih (Ljubljana)

Izvršni urednik za tuzemnu i inozemnu razmjenu /

Executive Editor for Publications Exchange

Martin Previšić

Tajnik uredništva / Editorial Board Assistant

Dejan Zadro

Adresa uredništva/Editorial Board address

Zavod za hrvatsku povijest, Filozofski fakultet Zagreb, Ivana Lučića 3, HR-10 000, Zagreb

Tel. ++385 (0)1 6120 150, 6120 158, faks ++385 (0)1 6156879

Časopis izlazi jedanput godišnje / The Journal is published once a year

Časopis je u digitalnom obliku dostupan na / The Journal in digital form is accessible at

Portal znanstvenih časopisa Republike Hrvatske „Hrčak“ http://hrcak.srce.hr/radovi-zhp

Financijska potpora za tisak časopisa / The Journal is published with the support by Ministarstvo znanosti, obrazovanja i športa Republike Hrvatske

Časopis je indeksiran u sljedećim bazama / The Journal is indexed in the following databases: Directory of Open Access Journals, EBSCO, SCOPUS, ERIH PLUS, Emerging Sources Citation Index - Web of Science 


\title{
Naslovna stranica / Title page by
}

Iva Mandić

\section{Grafičko oblikovanje i računalni slog / Graphic design and layout Marko Maraković}

\author{
Lektura / Language editors \\ Samanta Paronić (hrvatski / Croatian) \\ Dražen Nemet (engleski / English) \\ Tisak / Printed by \\ Tiskara Zelina d. d., Sveti Ivan Zelina \\ Naklada / Issued \\ 250 primjeraka / 250 copies
}

Časopis je u digitalnom obliku dostupan na Portalu znanstvenih časopisa Republike Hrvatske „Hrčak“ http://hrcak.srce.hr/radovi-zhp

The Journal is accessible in digital form at the Hrcak-Portal of scientific journals of Croatia http://hrcak.srce.hr/radovi-zhp 